\title{
HIV and Incentives for Monogamy among Gay Men*
}

\author{
Nick W. Papageorge ${ }^{\dagger}$
}

March 6, 2012

\begin{abstract}
I examine how AIDS affected patterns of sexual behavior among gay men. I focus on monogamy, studying HIV + and HIV - men both before and after a medical innovation called HAART. I find that (1) HAART-induced health improvements increased demand for sex partners among HIV + subjects; (2) HIV - subjects shifted away from precautionary behavior after HAART introduction and (3) Exits from multiple partners to monogamy also increased after HAART was introduced. This latter result is explained by quicker and safer post-HAART partner searches, which encouraged agents to "repartner", i.e., leave unsatisfactory partnerships in favor of more suitable mates. For HIV+ subjects, this "repartnering" effect was underscored by HAART-induced improvements in health and life-expectancy, which rendered them more valuable as long-term mates.
\end{abstract}

JEL Classification: I1 J2

\footnotetext{
*I gratefully acknowledge support from the Center for Research in Economics and Strategy (CRES), in the Olin Business School, Washington University in St. Louis along with helpful comments and suggestions from: Kelly Bishop, Melanie Blackwell, Tat Chan, Sebastian Galiani, Vivek Gupta, Barton Hamilton, Pamela Jakiela, Alvin Murphy, Karen Norberg, Juan Pantano, Robert Pollak, Raul SantaeulaliaLlopis, Robert Walker, and participants at the Development and Public Policy seminar at Washington University in St. Louis and the Midwest Economics Association annual meeting. All errors are my own.

${ }^{\dagger}$ Department of Economics, Washington University in St. Louis. Email: papageorge@wustl.edu.
} 


\section{Introduction}

Major medical shocks - like illness, epidemics and treatment breakthroughs - can induce widespread shifts in behavior. Illnesses limit physical activity, but those limits can be alleviated by effective treatments. For those at risk of becoming ill, fear of infection incentivizes taking precautions. Treatment innovation encourages riskier behavior by reducing the expected cost or likelihood of a disease. More broadly, behavior responses to medical shocks can lead to profound social transformation. The invention of birth control pills, for example, is credited with shifting marriage patterns and women's labor market participation in the U.S. And more recently: the AIDS epidemic and resulting political cohesion surrounding gay men's health needs helped to bring about the modern gay rights movement 1 Though these two examples are distinct in scope, they illustrate the vast and varied potential impact of medical shocks.

I examine how AIDS affected patterns of sexual behavior among gay men. I pay particular attention to monogamy, a sexual behavior associated with long-term partnerships, like marriage. This focus allows me to address homosexual family formation and its responsiveness to exogenous shifts in incentives. Following from this perspective, if AIDS shifted monogamous behavior, it would potentially affect markets that respond to families and family formation, including, for example, those for insurance, housing and adoption. Beyond its family-economical component, monogamy allows me to capture two other dimensions of sexual behavior change. First, monogamy mechanically amounts to intercourse with one versus multiple partners. AIDS-induced physical limitations encouraged the former, less strenuous activity over the latter. Second, monogamy is a well-documented precautionary measure against HIV. Those at risk of contracting HIV could practice monogamy to avoid infection. In summary, this study exploits the fact that monogamy is a multifarious sexual behavior in order to examine how AIDS: shifted incentives, altered sexual behavior and changed how gay men form families.

In 1996, an HIV treatment known as HAART was introduced. As the first effective treatment for HIV infection, HAART quickly and unexpectedly reshuffled incentives for sexual behavior and monogamy $\left.\right|^{2}$ As such, HAART introduction provides a unique op-

\footnotetext{
${ }^{1}$ See, for example, Andriote (1999). For a much earlier example, some historians claim that economic and social responses to the Black Death were an instrumental step towards the industrial revolution.

${ }^{2}$ HAART stands for highly active anti-retroviral treatment. There is no vaccine or cure for HIV or AIDS, but HAART is the current standard treatment. 1996 is marked as the year when two crucial clinical guidelines that comprise HAART came to be commonly acknowledged (Flint et al. 2004)). First, protease inhibitors (made widely available towards the end of 1995) would be an effective HIV treatment. Second, several anti-retroviral drugs taken simultaneously could indefinitely delay the onset of AIDS. The principle behind drug combination is two-fold. When confronted with multiple drugs, the virus must
} 
portunity to identify how AIDS induced widespread changes in sexual behavior. In particular, I examine the impact of HAART on both HIV + and HIV - gay men. For those infected with HIV, HAART drastically improved physical health and prolonged life; for those at risk of contracting HIV, HAART lowered both the expected costs and likelihood of infection. Both of these effects would presumably discourage monogamous behavior. However, if seeking a monogamous mate includes a period of search involving sex with multiple partners, HAART lowered the risk associated with partner search. Also, more individuals on the sex market could thicken the market for long-term partners. Finally, by increasing life expectancy and improving health, HAART made HIV+ men more valuable as long term mates. Together, these effects would encourage monogamy.

This study exploits the quasi-experimental nature of HAART introduction and employs panel data on the number of sex partners reported by HIV - and HIV + gay men over various phases of the AIDS epidemic. Regarding the six months prior to their interview, each subject reports: no intercourse (celibacy), intercourse with a single partner (monogamy) or intercourse with multiple partners. Since I observe transitions among several sexual behaviors along with attrition and death, the appropriate econometric framework is a survival model of competing risks. The main findings of the study are:

1. HAART-induced health improvements increased demand for sex partners among $\mathrm{HIV}+$ subjects.

2. HIV - subjects shift away from precautionary behavior after HAART introduction.

3. Exits from multiple partners to monogamy also increase in the post-HAART era. Among the HIV-, I argue that this movement is driven by HAART-induced decreases in the cost of search for monogamous partners. I also find evidence of a "repartnering" effect: quicker and safer partner searches after HAART introduction encouraged subjects to find more suitable mates. For HIV+ subjects, this increase in monogamy was further underscored by HAART-induced improvements in health and life-expectancy, which rendered positive more valuable as long-term mates.

The remainder of this paper is organized as follows: Section 2 provides a background along with theoretical predictions. Section 3 describes the data set used in this study, with particular attention on how monogamy is defined. Section 4 discusses the econometric strategy. Results are discussed in Section 5 and Section 6 concludes.

mutate in multiple, independent ways for the specific combination to become ineffective. Also, combining drugs into "cocktails" dramatically increases the number of treatment options for any given number of available drugs. 


\section{Background and Predictions}

The early years of the AIDS epidemic were characterized by a rapid and drastic increase in gay men reporting either monogamy or celibacy in favor of multiple partners $!^{3}$ For HIVsubjects, precaution likely explains this behavioral shift. According to (Smith, 1998):

The idea of monogamy as a preventive measure for HIV infection originated in the gay male community in the earliest months of the AIDS epidemic. At that time, all that was known about the cause of AIDS was that it seemed correlated with having had large numbers of sexual partners.

Reniers (2008) finds a similarly motivated increase in monogamy among heterosexuals in sub-Saharan Africa. In the U.S, Francis (2008) finds evidence that HIV- subjects substitute between homosexual and heterosexual sex to limit exposure to HIV. Next, since the vast majority of gay men are not infected with HIV, the precaution-induced limited supply of HIV - subjects engaging in sex with multiple partners increased search costs for sex, leading to a similar move towards monogamy and celibacy among HIV+ subjects. Health deterioration among the HIV+ underscored this rise.

HAART introduction would presumably reverse these effects. First, HAART led to health improvements among the HIV + , implying increases in demand for sexual partners. This demand shift is consistent with findings in Lakdawalla, Sood, and Goldman (2006), who exploit exogenous variation in HAART access to show a causal relationship between HAART-use and increased demand for sex among HIV+ individuals $4^{4}$ They go on to argue that this increase might have reduced the welfare of HIV - individuals by enlarging the pool of positive individuals on the sex market. I consider the effect of HAART on HIV - gay men explicitly. First, HAART-induced health improvements effectively lowered the expected cost of HIV infection. Second, HAART functions by decreasing the viral load of infected subjects, thus lowering HIV transmission rates for a given sex act with

\footnotetext{
${ }^{3}$ In fact, by 1984, some prominent activists in the gay community argued that gay men might respond to the growing epidemic by eschewing the hedonism and adventurism of the early gay rights movement in favor of relationships and long-term compatibility. See, for example, White and Lake (1980).

${ }^{4}$ Later contributions on how sex behavior respond to AIDS and HIV treatment innovation include: Mechoulan (2007), Auld (2003), and Auld (2006).
} 
a positive partner. Together, these effects would not necessarily lower welfare for HIVsubjects, but would incentivize a shift away from precautionary sexual behavior. As the majority of gay men are HIV-, this shift in precautionary behavior would reinforce increased partners among the HIV+. In summary, then, we would expect increased exits from monogamy and celibacy after HAART introduction among both HIV - and HIV+ subjects. However, this prediction is incomplete since it ignores the family economical component inherent to monogamous behavior.

Goldin and Katz (2002) show that medical innovation can have a profound effect on family structure and family formation. My focus on monogamy connects to this research since monogamy is not simply sex with one versus multiple partners, but also embodies a sexual behavior inherent to long-term partnerships. Monogamy, then, is a proxy for marriage-like behavior and this study of monogamy permits an analysis of the family economical impact of medical innovations like HAART. First, if partnership formation requires a period of partner search, the introduction of HAART rendered the search process less dangerous for the uninfected and would also thicken the market for potential partners.$^{5}$ In other words, the subset of subjects hoping to find a partner would do so more easily and quickly. Second, HAART-induced health improvements and life-expectancy increases rendered post-HAART HIV + subjects more valuable as long-term mates ${ }^{6}$ To understand why, I appeal to previous economic work on marriage and divorce. Stevenson (2007) and Stevenson and Wolfers (2007) find that an institutional shift lowering divorce costs can decrease agents' willingness to form a relationship at all. Easing divorce laws, for example, effectively shortens the expected length of a partnership. Subjects respond with decreased willingness to invest in relationship-specific capital. I apply this idea to medical innovation. HAART-induced health improvements and life-expectancy increases

\footnotetext{
${ }^{5}$ For this point, consider an exogenous upward shift in the arrival rate of partners. See, for example, Burdett and Mortensen (1980).

${ }^{6}$ This effect would be underscored by decreased fear of infection on the part of HIV - agents considering a partnership with an HIV+ subject. This decreased fear would reflect both decreased transmission rates and lower cost of HIV infection. For non-economic work on changing perceptions of HIV, see, for example, Herlitz and Steel (2000).
} 
raised both the expected length and value of a partnership with an HIV+ individual. The analogous prediction is that agents responded with greater willingness to invest in relationship-specific capital. In summary, then, the family economical impact of HAART might be an increase in exit rates from multiple partners to monogamy in the post-HAART era.

\section{Data}

To identify how the AIDS epidemic and HAART induced changes in sexual behavior, I use the public data set from the Multi-Center AIDS Cohort Study (MACS), an ongoing study (beginning in 1984) of the natural and treated histories of HIV infection in homosexual and bisexual men conducted at four sites: Baltimore, Chicago, Pittsburgh and Los Angeles.7 The data set is particularly well-suited to this project since it contains information on health status and sexual behavior both before and after HAART introduction. At each biannual visit, data are collected on: sexual practices and demographic and psychosocial characteristics. Subjects also provide blood samples, which permit direct measurement of CD4 count, an indicator of immune system health. The full MACS data set contains information on 5,519 subjects at 41 possible visits for a total of 98,886 subject-visits. Given the length of the sample period and missing visits, selection due to attrition may be of concern. To account for this possibility, I allow attrition to be a competing destination in subsequent competing risks analysis. As a robustness check, I also assume that attrition

\footnotetext{
${ }^{7}$ Data in this manuscript were collected by the Multicenter AIDS Cohort Study (MACS) with centers (Principal Investigators) at The Johns Hopkins Bloomberg School of Public Health (Joseph B. Margolick, Lisa P. Jacobson), Howard Brown Health Center, Feinberg School of Medicine, Northwestern University, and Cook County Bureau of Health Services (John P. Phair, Steven M. Wolinsky), University of California, Los Angeles (Roger Detels), and University of Pittsburgh (Charles R. Rinaldo). The MACS is funded by the National Institute of Allergy and Infectious Diseases, with additional supplemental funding from the National Cancer Institute. UO1-AI-35042, 5-MO1-RR-00052 (GCRC), UO1-AI-35043, UO1-AI-35039, UO1-AI-35040, UO1-AI-35041. For ethical considerations related to this study, please see the MACS website located at http://www.statepi.jhsph.edu/macs/macs.html.
} 
is random and show that results do not change significantly. 8

To construct the subsample for analysis, I drop subjects and observations where: HIV status is unclear, sex information is missing, if missed visits lead to ambiguity in the length of sex behavior spells or if subjects were administratively censored $!^{9}$ Also, the earlier years of the AIDS epidemic were characterized by dramatic changes in sexual behavior that are difficult to quantify since I do not observe pre-AIDS behavior. Instead, my research design is to concentrate on pre- versus post-HAART changes. Since I do not want to confound these changes with early epidemic shifts, I focus on observations after 1991:10 I also cut observations from the last visit since subjects' deaths are often not reported in data until 1-2 periods after-the-fact and I do not want to confuse death with attrition. The resulting subsample for analysis consists of 3,327 subjects and 45,303 subject-visits. In what follows, I provide summary statistics for the subsample and then go on to describe how I exploit pre- versus post-HAART behavior and how I construct sexual behavior spells for subsequent competing risks analysis.

\subsection{Summary Statistics}

Tables 1 presents descriptive statistics for the analysis sample. Average age at the start of the epidemic is 33.16 with a range of 18 to 70.5 . $18 \%$ are subjects are non-white and over $57 \%$ have a college degree ${ }^{11} 21 \%$ of observations report celibacy at time $t$ versus $26 \%$

\footnotetext{
${ }^{8}$ Throughout the remainder of the paper, I refer to a number of specification tests and robustness checks. They are described in greater detail and their results presented in the Appendix.

9 Due to funding cuts, a number of HIV - subjects were administratively censored between $1992-$ 1994. The censoring occurred as follows: riskier HIV - men were kept on and less risky HIV - men were randomly censored. I bypass problems associated with any potential sample selection bias by pinpointing censored individuals and dropping them from the analysis for the entire sample period. As the precise algorithm determining censorship is unknown, I cannot be sure that I am controlling for this.

${ }^{10}$ Results are robust to the inclusion of spells begun before 1990 .

${ }^{11}$ Kaslow and Ostrow (1987) address the question of representativeness of the MACS sample. If we compare our sample to those used in Francis (2008), subjects in this study are more educated, but with comparable income. Compared to data used in Lakdawalla et al. (2006), MACS subjects are more likely to be white and more educated. Note that we control for these and other sociodemographic characteristics in our econometric analysis. During recruitment, measures were taken to encourage participation and retention, including assurances of confidentiality and legal protections with regard to any sensitive information or disclosure of illegal activities. Administrators made efforts to recruit volunteers with
} 
for monogamy and $47 \%$ reporting intercourse with multiple partners. These proportions change dramatically according to disease status. About $43 \%$ of observations belong to subjects who are HIV + at baseline (see Table 2). Another $41 \%$ are never observed as $\mathrm{HIV}+($ Table 3) and the final $16 \%$ belong to subjects who are observed seroconverters, i.e., subjects who become HIV+. (Table 4).

In comparing subjects grouped by health status, several points are worth noting. First, baseline-positives are more likely than the two other groups to be non-white $(22 \%$ versus 14\%). Negatives are more likely to have a college degree (64\% versus 53\%). Regarding sex behavior, subjects are "observed anonymous" if they report intercourse with at least one anonymous partner during the first three years of the AIDS epidemic. $62 \%$ of baseline positives and negatives report anonymous intercourse compared to $74 \%$ of seroconverters. For baseline positives, this number likely reflects decreased risky sex behavior induced by deteriorating health. Indeed, baseline positives are more likely to report celibacy (26\% versus $15 \%$ for negatives and $18 \%$ for seroconverters). On the other hand, negatives are more likely than both other groups to report monogamy (28\% versus $25 \%$ for baseline positives and $24 \%$ for seroconverters). These proportions hint at the relationship between physical health and risk in determining sex behavior: although better health is associated with more sex, subjects engaging in riskier sex tend to be less healthy. Regarding health variables, average CD4 count among non-infected subjects is about 1025, in line with averages for healthy individuals in general. Baseline positives and seroconverters have an average CD4 count of 431 and 577, respectively. The difference between the latter groups is largely mechanical: baseline positives have been infected with HIV longer than seroconverters and so their immune system exhibits greater deterioration. Also, seroconverters,

specific characteristics. Nonetheless, Kaslow and Ostrow (1987) state: "There was, from inception, neither the possibility nor the intention of obtaining a totally 'representative' sample of homosexual men. Many participants presumably volunteered partly because they considered themselves at relatively high risk of developing AIDS." The possibility that MACS subjects have a stronger preference for risky sex than the population at large can strengthen my results. Specifically, this paper investigates sexual behavior changes in response to disease related incentives. Responses to disease-related incentives would presumably be stronger among a population with weaker preferences for risky sex. 
by becoming infected in later years, face a higher probability of survival until HAART introduction.

The impact of HAART becomes clear when we look at survival probability for different groups. Subjects who remain uninfected with HIV have a $93 \%$ chance of being alive in 2001 and this probability rises to $97 \%$ if I condition on survival until HAART. For baseline positives, unconditional survival probability is $32 \%$ compared to $55 \%$ for seroconverters, which again reflects the difference in the length of time since infection. However, conditional on survival until HAART, survival probability is strikingly similar (83\%) for baseline positives and seroconverters. In other words, HAART not only drastically increases survival probability for all HIV+ subjects. Rather, as long as an HIV+ subject survives until HAART, his chances of survival are largely independent of the length of time since infection. I also examine subject scores on the Center for Epidemiological Studies Depression Scale (CES-D) ${ }^{12}$ A score of sixteen or above (out of sixty possible points) is highly suggestive of depression. As expected, average scores are higher for groups that are likely sicker. In general, these statistics point to complex interactions among health, sociodemographic and psychosocial variables, underscoring the importance of including these variables as controls in subsequent regressions.13

\subsection{Sexual Behavior and Spell Construction}

At every sample period, subjects are asked whether they engage in sexual intercourse with other men, where intercourse is defined as oral and/or anal sex with a male during the period beginning six months before observation up until the time of observation. The resulting variable takes values 0 (no intercourse or 'celibacy'), 1 (intercourse with 1 partner or 'monogamy') or 2 (intercourse with multiple partners). This variable is potentially problematic since it does not distinguish between a long-term monogamous

\footnotetext{
${ }^{12}$ See, for example, Ostrow et al. (1989), for an example of CES-D scale use with the MACS data set.

${ }^{13}$ How I handle possible endogeneity of these regressors is discussed in Section 4.3.
} 
partnership and intercourse with a single partner. To address this potential problem, I repeat the main empirical analysis using explicit information on long-term partnerships that is, unfortunately, only available for two periods after HAART introduction. In periods where this information is collected, agents who report intercourse with a single partner are asked if this partner is a long-term partner versus a friend or anonymous partner. Agents are then asked if this partner is likewise monogamous. Despite limited availability of this information, results do not appreciably change. This suggests that the main, more general measure of monogamy used in subsequent analysis reliably captures monogamous behavior. 14

Another potential issue with the sex variable used in this study is that sexual activity often includes many modes of behavior, i.e., it might be overly restrictive to focus attention solely on oral and anal intercourse. On the other hand, oral intercourse is far less likely than anal sex to lead to HIV transmission so that the sex variable used in analysis might not be restrictive enough. To address these potential issues, I repeat analysis with alternative sex variables. First, I count any sort of sexual activity as intercourse when constructing a measure of sexual partners. Second, I count only anal sex partners as sexual partners. Results - found in the appendix - are robust to these changes.

Because this study uses panel data, spell construction for subsequent use in duration analysis requires some explanation. First, I observe the subject repeatedly over time, requiring estimation techniques that allow for multiple observations for each spell. Second, data is grouped, which means that I observe spell end at the interview date even though transition could have occurred at any point during the six months prior to observation. With this in mind, spells are constructed as a set of subsequent observations where the

\footnotetext{
${ }^{14}$ I might still mistake a long-term monogamous partnership with serial monogamy, i.e., repeated relationships that are one period in length. To address this issue, I use data asking monogamous men how long they have been with their monogamous partner. The issue with this data is that it is simply inconsistent with the passage of time, exhibiting jumps in partnership length that are impossible. That said, spell lengths constructed for analysis are positively correlated with spell partnership lengths reported with a correlation coefficient near 0.5 depending on exclusion rules. The measure used in analysis performs worst for short partnerships, which makes since under the assumption that subjects with a new partner might not report him as a long term mate.
} 
subject reports the same sexual behavior; the spell ends when the subject reports a different sexual behavior, dies, attrits, or is censored. It is possible to observe several spells of sexual behavior for any given subject. In the econometric analysis, I take account of repeated spells of the same individual by controlling for the number of previous spells of a given sexual behavior. I also cluster errors at the subject level ${ }^{15}$

\subsection{HAART Introduction as Intent-to-Treat Analysis}

I treat the introduction of HAART as an unanticipated shock, justifying this approach with two observations. First, promising treatments for HIV were introduced somewhat regularly during the pre-HAART era and generally proved ineffective. When HAART emerged, its effectiveness was both speedy and surprising to such a degree that the socalled "Lazarus effect" was observed among survivors who had resigned themselves to impending death (Brashers et al., 1999). Second, HAART was not a specific medication that was developed and improved over time such that subjects would form expectations over improved effectiveness. Rather, most components of HAART already existed prior to 1996 and were, when used in isolation, mostly ineffective. The key insight was the union of several existing technologies.

It is plausible to assume that HIV + subjects who use HAART are fundamentally different from those who do not (even after controlling for health status) and that this difference relates to these subjects' sexual behavior. An example would be that HIV+ subjects who use HAART are more likely to remain in a monogamous partnership to exploit the resulting economies of scale in order to help allay the cost of HAART. Use of the post-HAART dummy instead of individual-level HAART-usage circumvents this problem: although subjects can choose whether to take HAART, they cannot choose whether or not

\footnotetext{
${ }^{15}$ Main results are robust to different exclusion rules for ambiguous spell length. For example, under the hypothesis that a long-term monogamous partnership might include periods without intercourse, I repeat analyses allowing for up to two consecutive periods of celibacy during spells of monogamy. Main results are robust to these changes. See Appendix for details.
} 
HAART exists. For HIV+ subjects, use of the HAART era dummy variable essentially amounts to an intent-to-treat analysis.

1996 is generally marked as the year that HAART became the standard treatment for HIV infection. Following other studies on HAART, I consider activity occurring between 10/1/84 and 9/30/95 as comprising the pre-HAART era and activity between 4/1/96 and $3 / 30 / 04)$ to comprise the post-HAART era $!^{16}$ Figures 16 depict sex behavior over time. I demarcate HAART introduction with two vertical lines indicating the time interval during which first exposure to HAART might have occurred for different subjects.

In looking at these figures, note that monogamy and celibacy increase at the start of the AIDS epidemic, replacing intercourse with multiple partners. Changes occurring thereafter and at HAART introduction are less drastic. For HIV - subjects, there is an upward trend in celibacy, likely due to an aging cohort. This trend shifts downward when HAART is introduced and continues its upward climb. Monogamy trends slightly downward in the years before HAART and then shifts more decidedly downward after HAART introduction. Conversely, HAART introduction appears to coincide with an upward shift in sex with multiple partners after HAART introduction. These dynamics align with the notion that HAART introduction deincentivized precautionary behavior among uninfected subjects. In the case of HIV+ subjects, celibacy trends upward until HAART introduction, at which point the increase ceases and perhaps even reverses. When considering shifts in monogamy and sex with multiple partners, the trends are less clear around the time of HAART introduction. However, HIV+ subjects are facing: health improvements, a new market for sex partners and changing incentives for long-term mates ${ }^{17}$ The depicted trends are not suited to capturing the complexity of these shifts. For that, I turn to more formal econometric analysis.

\footnotetext{
${ }^{16}$ I repeat econometric analysis assuming different periods of HAART introduction. Main effects are similar if the post-HAART era is set to begin up to 1.5 years later or 1 year earlier. Basic HAART-induced effects disappear if I move the date of introduction any further in either direction.

${ }^{17}$ The upward tick in HIV + subjects reporting multiple partners at the end of 2003 is puzzling. Note that results are robust to non-inclusion of the last six periods of data.
} 


\section{Econometric Framework}

Interest lies in ascertaining how certain covariates impact hazard rates of exit from spells of one specific sexual behavior to another. For example, I investigate how HAART introduction impacted exit rates from monogamous spells to spells of intercourse with multiple partners. Analysis is complicated by the possibility of exits to multiple mutually exclusive destinations; we might observe a competing event that precludes observation of our event-of-interest. Specifically, a subject may exit from monogamy to death or celibacy, impeding the econometrician's ability to observe the subject's exit to multiple partners. In what follows, I discuss theoretical approaches to modeling such competing risks data and then describe the model used in this paper 18

\subsection{Competing Risks}

A traditional approach to modeling hazard rates with competing risks data begins with destination-specific hazard functions. Consider the following example: from monogamy the econometrician might potentially observe failures of type $f \in\{0,2,3\}$ where 0 refers to celibacy, 2 refers to non-monogamy and 3 refers to death. Suppose that $f=2$ (multiple partners) is the destination-of-interest. The destination-specific instantaneous rate of exit to destination $f$ is defined as:

$$
\lambda_{f}(t)=\lim _{h \rightarrow 0} \frac{\operatorname{Pr}(t \leq T<t+h, f \mid T>t)}{h}, \quad f \in\{0,2,3\},
$$

where $t$ denotes spell duration and $T$ is failure time. Exploiting the proportional hazards assumption, obtain:

$$
\lambda_{f}\left(t ; x_{i}\right)=\lambda_{f 0}(t) \exp \left\{x_{i}^{T} \beta_{f}\right\}, \quad f \in\{0,2,3\}
$$

\footnotetext{
${ }^{18}$ As a robustness check, I show that use of a proportional hazards cox model yields results that are qualitatively similar to results of the main analysis of this paper, i.e., results are not driven solely by use of competing risks methods.
} 
where $x$ is a vector of covariates that (proportionally) impact exit rates and $\beta_{f}$ is a vector of coefficients that determine how $x$ impacts exits to destination $f$. Here, $\lambda_{f 0}(t)$ is the baseline hazard rate of exit to destination $f$. Estimates of $\beta$ are obtained by maximizing the following partial likelihood function:

$$
L^{P}\left(\beta_{0}, \beta_{2}, \beta_{3}\right)=\Pi_{f \in\{0,2,3\}} L_{f}\left(\beta_{f}\right)
$$

Denoting $d_{f}$ as the number of individuals who exit to destination $f$ and $R\left(t_{i f}\right)$ as the "risk-set" (the set of spells that, along with spell $i$, are at risk of exit to destination $f$ at spell-length $t$ ), obtain:

$$
L_{f}\left(\beta_{f}\right)=\Pi_{i=1}^{d_{f}}\left(\frac{\exp \left\{x_{i}^{T} \beta_{f}\right\}}{\sum_{l \in R\left(t_{i f}\right)} \exp \left\{x_{l}^{T} \beta_{f}\right\}}\right) .
$$

Note that if risks are independent, $L^{P}\left(\beta_{0}, \beta_{2}, \beta_{3}\right)$ can be jointly maximized by maximizing $L_{f}\left(\beta_{f}\right)$ for each $f$. If one is interested in exits from monogamy in general, the above formulation is reasonable. If one is interested in how a specific covariate affects exits from monogamy to a specific destination, coefficient interpretation is no longer straightforward.

An approach to estimation of exits to a specific destination amounts to estimation of the destination-specific likelihood function, which is the $f$ factor of the partial likelihood defined above. This method essentially treats spells that end in exits to alternative destinations as randomly censored, potentially introducing bias. Indeed, if one is interested in the effect of HAART introduction on exits to monogamy, it would be incorrect to ignore the fact that HAART affects exit rates from monogamy to both death and celibacy.

To understand this point, consider the following plausible scenario. Suppose that there are two groups of HIV+ monogamous individuals and that, for given health, Group 1 has greater tendency to exit to celibacy and lower tendency to exit to multiple partners compared with Group 2. Further, suppose that better health implies higher exit rates to 
multiple partners and lower exit rates to celibacy for both Group 1 and Group 2. In other words, both groups respond to health incentives, but Group 1 has weaker unobserved preferences for sex with multiple partners. Next, suppose that HAART is introduced. Group 2 individuals exit monogamy to multiple partners at higher rates and Group 1 individuals exit monogamy to celibacy at lower rates. The key point is that if exits to competing destinations are treated as censored, one might find that the exit rate to multiple partners remains unchanged. After HAART introduction, exits to multiple partners increases, but decreased exits to celibacy increases the size of the risk pool, too, which would lower the estimated hazard rate. This stylized example illustrates the need to appropriately account for competing risks in order to correctly determine how HAART affects sex behavior.

\subsection{Cumulative Incidence}

An alternative approach to modeling competing risks data focuses on the cumulative incidence for a particular cause of failure and is defined as:

$$
F_{f}(t)=\operatorname{Pr}(T \leq t, \text { exit to } f)=\int_{0}^{t} \lambda_{f}(u) \exp \left\{-\int_{0}^{u} \sum_{f \in\{0,2,3\}} \lambda_{f}(w) d w\right\} d u
$$

The cumulative incidence function (CIF) gives the probability of failure from cause $f$ by time $t$ and in the presence of other possible causes. Note that the CIF depends upon the destination-specific hazard functions for all destinations. However, it is not straightforward to calculate the impact of a change in a covariate on the cumulative incidence function using cause-specific hazards. Covariates affect the hazard rates of exit to each of the competing destinations and the cumulative incidence function is a nonlinear function of these effects and of the baseline hazards. Fine and Gray (1999) propose an alternative model to handle competing risks. They specify a model for the so-called hazard of the subdistribution, defined as follows 


$$
\bar{\lambda}_{f}(t)=\lim _{\delta \rightarrow 0^{+}}\left(\frac{\operatorname{Pr}(t<T<t+\delta \wedge f \mid(T \geq t) \vee(T \leq t \wedge \neg f))}{\delta}\right),
$$

where $T$ denotes failure time. A key difference in this method is that the risk-set associated with $\bar{\lambda}_{f}(t)$ is "unnatural" in that individuals who exit to destinations other than $f$ are not actually at risk at spell-length $t$. The risk set for individual $i$ is defined as:

$$
\bar{R}\left(t_{i f}\right)=\left\{j:\left(\text { exit to } f \wedge T_{j} \geq T_{i}\right) \cup\left(T_{j} \leq T_{i} \cap \neg f \cap C_{j} \geq T_{i}\right)\right\}
$$

where $C$ is censoring time. In this hypothetical cohort, an individual with failure to destination other than $f$ is kept "at risk" for failure from the cause-of-interest until time $C$, when $T<C$. Essentially, the sub-hazard specified by this expression models failures in the form of the event of interest, but retains subjects who have exited to other destinations in the risk pool because failure due to other events has precluded their failure due to the event of interest. Returning to the aforementioned scenario: Group 1 individuals who exit to celibacy in the pre-HAART era are kept "at risk" of exit to multiple partners. Then, when exits to celibacy decrease in the post-HAART era, one can still measure post-HAART increases (driven by Group 2) in exit rates to multiple partners.

Exploiting the proportional hazards assumption, obtain:

$$
\bar{\lambda}_{f}\left(t ; x_{i}\right)=\bar{\lambda}_{f 0}(t) \exp \left\{x_{i}^{T} \beta_{f}\right\}
$$

where $\bar{\lambda}_{f 0}(t)$ is the baseline sub-hazard, leading to the following log partial likelihood:

$$
\log \bar{L}^{P}(\beta)=\sum_{i=1}^{N} I(i \text { exits to } f)\left(x_{i}^{T} \beta-\log \sum_{j \in \bar{R}\left(t_{i f}\right)}\left\{\pi_{j i} \exp \left(x_{j} \beta\right)\right\}\right) .
$$

where $I$ is the indicator function and $\pi_{j i}$ are the weights on subjects who have failed due to a competing risk. ${ }^{19}$

\footnotetext{
${ }^{19}$ Formally, $\pi_{j i}=1$ for subjects who do not experience a competing event. At $t_{i}$, for subjects who have
} 
In the subsequent analysis, I also relax the proportional hazards assumption. Rewrite Equation 7 as follows (where, for expository purposes, assume there is only one variable $\left.x_{1}\right)$ :

$$
\tilde{\lambda}_{f}\left(t ; x_{i}\right)=\bar{\lambda}_{f 0}(t) \exp \left\{x_{i 1}\left(\beta_{f 1}+\psi_{1} t\right)\right\}
$$

This formulation allows the impact of covariates to vary by spell length. For example, the introduction of HAART might have a negligible impact on exit rates shorter partnerships, but a large and positive impact on longer partnerships. Relaxing the proportional hazards assumption permits exploration of this possibility ${ }^{20}$

\subsection{Econometric Model}

The main analysis of the paper employs the competing risks framework as explained above to explore the cumulative incidence of exit to and from multiple partners, monogamy, and celibacy. For destinations $f$, the likelihood function is constructed using:

$$
\tilde{\lambda}_{f}\left(t ; w, z_{t}\right)
$$

where $\tilde{\lambda}_{f}(\cdot)$ is defined as in the previous section. The matrix of time-invariant covariates $w$ includes: mean-centered CD4 count at spell begin (where the mean is for subjects of the same serostatus), mean centered viral load at spell begin (for subjects HIV + at spell begin), race (white versus non-white) and education (high school diploma or less versus exited to a competing destination at $t_{j}$ :

$$
\pi_{j i}=\frac{\hat{S}_{c}\left(t_{i}\right)}{\hat{S}_{c}\left\{\min \left(t_{j}, t_{i}\right)\right\}}
$$

where $\hat{S}_{c}(t)$ is the Kaplan-Meier estimate of the survivor function for the censoring distribution evaluated at $t$. If the likelihood of being censored increases with spell length, the numerator will decrease with $t_{i}$ relative to the denominator. Therefore, subjects who have exited to a competing destination will have lower weight as the likelihood of censorship increases.

${ }^{20} \mathrm{As}$ the dataset for analysis is constructed from of a panel data set, I also allow for multiple records per subject and grouped data. See, for example, Cameron and Trivedi (2005), on these topics. 
some college versus college degree). I also include a variable controlling for the number of previous spells of the same behavior observed for each subject. This variable accounts for subject-level variability in the propensity to switch sexual behaviors as multiple spells imply multiple previous exits. A dummy variable for anonymous sex indicates if a subject reported at least one instance of intercourse with an anonymous partner, defined (in the survey) as someone that the subject would not be able to locate. All variables are interacted with serostatus at spell start so that I can estimate separate effects for each group within a single regression model. Note that health and sociodemographic variables that constitute $w$ are observed to vary over spells. However, I keep them constant to avoid potential endogeneity bias that might arise from correlation between these variables and spell length.

The matrix of time-varying covariates $z_{t}$ includes: HAART-era dummies, age, and age-squared, CES-D score and income, all likewise interacted with serostatus at spell start. Since there is missing data for some variables, I include in all regressions a series of dummies indicating if data is missing for: CD4 count, viral load, CES-D score and income ${ }^{21}$ I also include a dummy variable if the spell is left-censored. Finally, I conduct a number of robustness checks on this choice of variables to ensure that no single control variable drives results. Details are found in the appendix.

\section{Results}

Tables 5,8 present main results from estimation of the cumulative incidence model described in the previous section. The first line of Table 5 reports post-HAART dummy coefficients for HIV - subjects for exits to and from each sex behavior: celibacy, monogamy, and multiple partners. The columns are labeled with spell and destination ( $\mathrm{C}$ for celibacy, MO for monogamy and MP for multiple partners). In each case, exits to either death, at-

\footnotetext{
${ }^{21}$ See, for example, Brunner and Sonstelie $(2003)$ for use of this method.
} 
trition or to a sex behavior other than the destination-of-interest are treated as competing risks. For instance, the first column, labeled C-MO presents coefficients on hazard rates of exit from celibacy to monogamy, where exits to death, attrition or multiple partners are treated as competing risks.

I begin with exits from and to celibacy: results indicate that HIV + agents exit celibacy at higher rates when they are healthier, where health is measured by CD4 count viral load. This holds for negative subjects for exits to monogamy. After controlling for health, HAART introduction also brought higher transition rates to multiple partners, as measured by the post-HAART dummies ${ }^{22}$ In Columns 3 and 5, I examine exits into celibacy from monogamy and multiple partners, respectively. Here, note that increased age is generally associated with transitions to celibacy, as is poor health. Subjects who are observed anonymous exhibit higher exit rates from celibacy multiple partners, which accords with anonymity as a revealed preference for more and riskier sex. On the other hand, a report of anonymous intercourse is also associated with decreased exit rates to monogamy from celibacy, a result reinforcing that monogamy is more complex than a number of partners. Next, a college degree and higher income are associated with lower exit rates from multiple partners to celibacy, a result suggests greater ease with which wealthier subjects locate partners. On the other hand, a higher CES-D score - suggestive of depression - predicts higher exits rates to celibacy. In general, these basic results accord with the notion that celibacy is more appealing for older or physically ill subjects and when fear of AIDS encourages safer sex behavior.

Consider transitions to multiple partners from monogamy (Column 4). For HIV- and $\mathrm{HIV}+$, younger and healthier subjects are more likely to exit to multiple partners. There is also a post-HAART upward shift in exit rates that is independent of health measures. Finally, subjects with numerous previous spells of monogamy are more likely to exit to multiple partners. These results are consistent with the view that sex behavior reflects

\footnotetext{
${ }^{22}$ Results are repeated for convenience in Table 6 with HIV + and pre-HAART as the baseline category.
} 
both physical health and precaution. HAART introduction lowered the cost and likelihood of HIV infection. Agents with strong preferences for sex with multiple partners, but who limited themselves to a single partner for fear of HIV infection, would tend towards more partners in the post-HAART era. HIV+ subjects, facing an increase in supply of HIV- subjects on the sex market, would also more easily find willing partners for sex. Continuing, Table 7 repeats results on hazard rates from monogamy to multiple partners. The first column and third column table corresponds to the results from Column 3 of Tables 5 and 6, respectively. The second and fourth rows shows results from analogous regressions where post-HAART dummy variables are interacted with spell length, the goal of which is to ascertain whether post-HAART changes in exit rates vary by spell length. I find that the post-HAART increase in exits from monogamy to multiple partners is concentrated among longer partnerships for both negative and positive subjects. I also find that anonymity and a college degree are associated with increased exit to multiple partners. These results reflect post-HAART decreased risk and cost of HIV infection and better health among the HIV+.

Next, consider exit rates from multiple partners to monogamy (Column 6 in Table 5 and Table 8, which is analogous to Table 7). Consistent with earlier results, I show that anonymity is associated with lower exit rates into monogamy from multiple partners. However, I also show that exit rates are higher in the post-HAART era and for subjects with better health measures. These results are puzzling if we maintain that monogamy can be understood simply as sex with one versus multiple partners. In fact, monogamy is a sexual behavior associated with long-term partnerships and this perspective helps to explain post-HAART dynamic results. Evidence of a post-HAART increase in exits to monogamy can be explained by a thicker market for partners. Agents already seeking a monogamous partnership in the pre-HAART era would find their search more effective due to the post-HAART thickening of the sex market. Another explanation is that pre-HAART monogamous agents, encouraged by the post-HAART thicker and safer sex 
market, leave unsatisfactory mates in search of a new, more suitable long-term partner. This "repartnering" effect would likely be strongest for HIV+ subjects since they also experience a sharp post-HAART increase in their value as long-term mates. In the next section, I examine the reparterning possibility further.

\subsection{Repartnering and Symptoms of Depression}

To gain further insight into post-HAART increases in exits to monogamy, I examine what sort of subjects are causing the increase. One possibility is that subjects entering monogamy at higher rates were engaged in multiple partner spells just before HAART came along. The observed jump in exits to monogamy would then be consistent with the notion of a "thicker" market for potential partners in the post-HAART era and the corresponding prediction that subjects already seeking partners before HAART will find them more easily after HAART. Alternatively, higher rates of exit to monogamy might be driven by subjects who were monogamous just prior to HAART introduction. This result would point to a "repartnering" effect, whereby subjects exit monogamous partnerships to resample the distribution of partners and then subsequently repartner. Table 9 presents results exploring the possibility of this "repartnering" effect, where I run regressions separately for HIV - and HIV + subjects.23 Specifically, I interact serostatus and the post-HAART dummy with partnership status just before HAART introduction.

For HIV - subjects, I find that the post-HAART jump in exits to monogamy are driven by subjects engaged in monogamy or intercourse with multiple partners immediately prior to HAART introduction. For HIV + subjects, the post-HAART jump is driven by subjects engaged in monogamy just before HAART. This result suggests that both HIV- subjects faced a thicker market for partners. Individuals aleady seeking monogamous partners in the pre-HAART era found them more easily after HAART introduction. For HIV-

\footnotetext{
${ }^{23}$ Separate regressions are only for ease of exposition. Important results do not change if I run a single regression for all subjects.
} 
and HIV + subjects, there is also evidence of a repartnering effect. Agents monogamous before HAART resampled the distribution of partners in the post-HAART era. That the increase in exits to monogamy is driven solely by "re-partnering" for HIV + subjects underscores the notion that HIV + subjects in the post-HAART era are more valuable as potential long term mates.

If $\mathrm{HIV}+$ subjects left monogamous partnerships to find more satisfactory partners in the post-HAART era, one would expect them to be more satisfied in general. To address this possibility, I examine CES-D scale scores constructed using subject answers to questions meant to ascertain symptoms of depression. I consider CES-D score changes for HIV+ subjects who are monogamous in the post-HAART era, are monogamous just prior to HAART, and for whom a gap consisting of sex with multiple partners was observed at some point prior to post-HAART monogamy. I compare these score changes to score changes for subjects who are likewise monogamous in the pre- and post-HAART eras, but who did not experience a similar gap. I also compare these score changes to those observed in non-monogamous subjects after HAART introduction. The aim is to ascertain whether subjects who repartnered, i.e., those who exhibit a post-HAART gap in monogamous behavior, experienced a decrease in depression symptoms beyond the decrease experienced by similar individuals who did not choose to repartner. I focus on the three years before and after HAART introduction and on subjects reporting intercourse of some kind 24 Table 10 contains descriptive statistics on subjects used in this analysis. Generally, health patterns are consistent with the sample at large and given that I am focussing on later

\footnotetext{
${ }^{24}$ As a robustness check, I repeat this analysis for different including various sample periods both before and after HAART introduction and find similar results.
} 
sample periods. Formally, I estimate the following differences-in-differences model:

$$
\begin{aligned}
\ln (\text { CESD Score }) & =M_{i t} \gamma+\alpha_{i} \\
& +I \text { (pre-HAART }, \text { non-monogamous }) \phi_{0} \\
& +I \text { (post-HAART, non-monogamous }) \phi_{1} \\
& +I(\text { pre-HAART }, \text { monogamous }) \phi_{2} \\
& +I \text { (pre-HAART }, \text { monogamous }) \phi_{3} \\
& +I(\text { pre-HAART }, \text { monogamous, with gap }) \phi_{4} \\
& +\epsilon_{i t},
\end{aligned}
$$

where $M_{i t}$ is a vector of control variables that includes age, age ${ }^{2}$ and mean-centered CD4-count for HIV+ subjects and $I(\cdot)$ is the indicator function. I estimate the model separately for HIV+ and HIV- subjects where the coefficient-of-interest is $\phi_{4}$. I wish to determine whether $\phi_{4}<0$ for HIV+ subjects. Note that the goal in this exercise is not to make a causal statement about the effect of repartnering; a causal claim would require random assignment into the repartnering group rather than the self-selection at work in this scenario. Rather, I expect subjects who leave an unsatisfactory partnership in favor of a more suitable partnership to be more satisfied thereafter. This exercise tests the hypothesis that such subjects are, in fact, measurably happier after repartnering.

For ease of exposition, I present results for 5 models (denoted M1-M5 in Table 11 . where each model adds an additional regressor. Model 1 contains a post-HAART dummy and shows a significant post-HAART score decrease, indicative of fewer symptoms of depression. In Model 2, I add an age polynomial, which strengthens the post-HAART effect. In Model 3, I include CD4 count, which accounts for some of the post-HAART effect. In Model 4, I compare monogamous and non-monogamous subjects, finding that both groups experience CES-D score improvements (decreases). Finally, in Model 5, I interact post-HAART monogamy with an indicator measuring whether or not the subject 
"repartnered" (exhibited a period of intercourse with multiple partners). I find that the post-HAART CES-D improvement is significant and negative for subjects who repartnered

$\left(\phi_{4}<0\right)$. In Table 12 , I show that the same dynamics are neither as strong nor significant for HIV-subjects. These results provide ancillary evidence that post-HAART movements into monogamy for $\mathrm{HIV}+$ subjects were driven by a desire to repartner due to postHAART shifts in incentives.

\section{Conclusion}

This study examines how AIDS induced changes in sexual behavior among gay men. I identify these shifts by examining the behavior of HIV - and HIV + gay men both before and after the introduction of HAART. As the first effective treatment for HIV infection, HAART shifted incentives for sexual behavior in a variety of ways. I find that HAARTinduced health improvements led HIV + subjects to demand more sex partners. Among HIV - subjects, I find that HAART introduction discouraged precautionary behavior by lowering both the expected cost and likelihood of HIV infection. Further, I argue that the increased pool of uninfected agents willing to engage in intercourse underscores the increase in partners observed among the infected. Together, these findings provide an alternative perspective on the impact of HAART on HIV - individuals. They did not necessarily face a welfare-reducing increase in the number of positive individuals on the sex market. Rather, uninfected subjects reduced precautionary sexual behavior in response to a medical intervention that reshuffled incentives surrounding HIV.

My focus on monogamy, a sexual behavior associated with long-term partnerships like marriage, permits me to analyze a more puzzling finding: that exit rates to monogamy from spells of multiple partners also increase in the post-HAART era. I find evidence that this dynamic is driven by a number of factors. First, the HAART-induced increase in sexual activity thickened the market for potential partners. Second, the post-HAART 
relative safety of partner searches encouraged agents to resample the distribution rather than remain in unsatisfactory partnerships. This "repartering" dynamic is the primary source of increased exit rates to monogamy among the HIV+. This makes sense since HAART-induced health improvements and longevity increases effectively increased the value of $\mathrm{HIV}+$ subjects as long-term mates, which increased willingness to invest in a long-term partnership with a positive individual.

More broadly, this study shows that when investments in long-term monogamous partnerships are more attractive, more monogamous partnerships are observed. Noting that monogamous sexual behavior can be an effective measure to slow the spread of AIDS, it follows that recent policies that encourage monogamous partnerships (gay marriage, domestic partnership benefits, etc.) might work to counteract the spread of HIV.

\section{References}

J.M. Andriote. Victory Deferred: How AIDS Changed Gay Life in America. University of Chicago Press, Chicago, 1999.

M.C. Auld. Choices, beliefs, and infectious disease dynamics. Journal of Health Economics, 22(3):361-377, 2003.

M.C. Auld. Estimating behavioral response to the aids epidemic. Contributions to Economic Analysis \& Policy, 5(1):1235-1235, 2006.

D.E. Brashers, JL Neidig, LW Cardillo, LK Dobbs, JA Russell, and SM Haas. 'in an important way, i did die': Uncertainty and revival in persons living with hiv or aids. AIDS Care, 11(2):201-219, 1999.

E. Brunner and J. Sonstelie. Homeowners, property values, and the political economy of the school voucher. Journal of Urban Economics, 54(2):239-257, 2003. ISSN 0094-1190. 
K. Burdett and D.T. Mortensen. Search, layoffs, and labor market equilibrium. The Journal of Political Economy, 88(4):652-672, 1980. ISSN 0022-3808.

A.C. Cameron and P.K. Trivedi. Microeconometrics: Methods and Applications. Cambridge University Press, Cambridge, 2005.

J.P. Fine and R.J. Gray. A proportional hazards model for the subdistribution of a competing risk. Journal of the American Statistical Association, 94(446):496-497, 1999.

S.J. Flint, L.W. Enquist, V.R. Racaniello, A.M. Skalka, et al. Principles of Virology: Molecular Biology, Pathogenesis, and Control of Animal Viruses. ASM Press, Washington, DC, 2004.

A.M. Francis. The economics of sexuality: The effect of hiv/aids on homosexual behavior in the united states. Journal of Health Economics, 27(3):675-689, 2008.

C. Goldin and L.F. Katz. The power of the pill: Oral contraceptives and women's career and marriage decisions. Journal of Political Economy, 110(4):730-770, 2002.

C.A. Herlitz and J.L. Steel. A decade of hiv/aids prevention in sweden: Changes in attitudes associated with hiv and sexual risk behaviour from 1987 to 1997. Aids, 14(7): $881,2000$.

RA Kaslow and DG Ostrow. The multicenter aids cohort study (macs): Rationale, organization and selected characteristics of the participants. American Journal of Epidemiology, 126:310-318, 1987.

D. Lakdawalla, N. Sood, and D. Goldman. Hiv breakthroughs and risky sexual behavior. The Quarterly Journal of Economics, 121(3):1063-1102, 2006.

Stephane Mechoulan. Risky sexual behavior, testing, and hiv treatments. Forum for Health Economics and Policy, 10(2):1-51, 2007. 
DG Ostrow, A. Monjan, J. Joseph, M. VanRaden, R. Fox, L. Kingsley, J. Dudley, and J. Phair. Hiv-related symptoms and psychological functioning in a cohort of homosexual men. American Journal of Psychiatry, 146(6):737, 1989.

G. Reniers. Marital strategies for regulating exposure to hiv. Demography, 45(2):417-438, 2008.

R.A. Smith. Encyclopedia of AIDS: A Social, Political, Cultural, and Scientific Record of the HIV Epidemic. Fitzroy Dearborn, Chicago, 1998.

B. Stevenson. The impact of divorce laws on marriage-specific capital. Journal of Labor Economics, 25(1):75-94, 2007.

B. Stevenson and J. Wolfers. Marriage and divorce: Changes and their driving forces. Journal of Economic Perspectives, 21(2):27-52, 2007.

E. White and T. Lake. States of desire: travels in gay America. EP Dutton, 1980. 


\section{Tables and Figures}

Table 1: Summary Statistics: Subsample for Analysis

\begin{tabular}{lccccc}
\hline \hline \multicolumn{1}{c}{ Variable } & Mean & Std. Dev. & Min. & Max. & N \\
\hline Age in 1984 & 33.16 & 7.61 & 18 & 70.5 & 3327 \\
Non-white & 0.18 & 0.38 & 0 & 1 & 3327 \\
High School & 0.12 & 0.33 & 0 & 1 & 3327 \\
College & 0.57 & 0.49 & 0 & 1 & 3327 \\
Income & 36706.74 & 16864.28 & 5000 & 55000 & 31358 \\
Celibate in Period t & 0.21 & 0.4 & 0 & 1 & 45303 \\
Monogamous in Period t & 0.26 & 0.44 & 0 & 1 & 45303 \\
Multiple Partners in Period t & 0.53 & 0.5 & 0 & 1 & 45303 \\
\% HIV+ at Baseline & 0.47 & 0.5 & 0 & 1 & 3327 \\
\% HIV- at Visit 41 & 0.4 & 0.49 & 0 & 1 & 3327 \\
\% Observed Seroconverter & 0.14 & 0.34 & 0 & 1 & 3327 \\
\hline
\end{tabular}

Table 2: Summary Statistics: Baseline HIV+

\begin{tabular}{lccccc}
\hline \hline \multicolumn{1}{c}{ Variable } & Mean & Std. Dev. & Min. & Max. & N \\
\hline Age in 1984 & 32.82 & 6.7 & 18 & 68 & 1559 \\
Non-white & 0.22 & 0.41 & 0 & 1 & 1559 \\
High School & 0.15 & 0.35 & 0 & 1 & 1559 \\
College & 0.53 & 0.5 & 0 & 1 & 1559 \\
Income & 34812.72 & 17555.83 & 5000 & 55000 & 13189 \\
CD4 & 431.39 & 290.07 & 0 & 3819 & 18296 \\
Viral Load & 61078.67 & 184375.59 & 0 & 5039648 & 9972 \\
CES-D Depression Score & 13.76 & 7.74 & 3 & 52 & 17446 \\
Observed Anonymous & 0.62 & 0.48 & 0 & 1 & 1559 \\
Alive at Visit 41 & 0.38 & 0.49 & 0 & 1 & 1559 \\
Alive at V41 if Post-HAART & 0.83 & 0.38 & 0 & 1 & 622 \\
Celibate in Period t & 0.26 & 0.44 & 0 & 1 & 19407 \\
Monogamous in Period t & 0.25 & 0.43 & 0 & 1 & 19407 \\
Multiple Partners in Period t & 0.49 & 0.5 & 0 & 1 & 19407 \\
\hline
\end{tabular}


Table 3: Summary Statistics: HIV-

\begin{tabular}{lccccc}
\hline \hline \multicolumn{1}{c}{ Variable } & Mean & Std. Dev. & Min. & Max. & N \\
\hline Age in 1984 & 34.14 & 8.51 & 18 & 70.5 & 1315 \\
Non-white & 0.14 & 0.35 & 0 & 1 & 1315 \\
High School & 0.1 & 0.31 & 0 & 1 & 1315 \\
College & 0.64 & 0.48 & 0 & 1 & 1315 \\
Income & 38999.38 & 15513.29 & 5000 & 55000 & 12917 \\
CD4 & 1025.1 & 351.7 & 7 & 3805 & 15437 \\
CES-D Depression Score & 12.64 & 7.4 & 3 & 57 & 17377 \\
Observed Anonymous & 0.62 & 0.49 & 0 & 1 & 1315 \\
Alive at Visit 41 & 0.93 & 0.25 & 0 & 1 & 1315 \\
Alive at V41 if Post-HAART & 0.97 & 0.18 & 0 & 1 & 663 \\
Celibate in Period t & 0.15 & 0.36 & 0 & 1 & 18672 \\
Monogamous in Period t & 0.28 & 0.45 & 0 & 1 & 18672 \\
Multiple Partners in Period t & 0.56 & 0.5 & 0 & 1 & 18672 \\
\hline
\end{tabular}

Table 4: Summary Statistics: Seroconverter

\begin{tabular}{lccccc}
\hline \hline \multicolumn{1}{c}{ Variable } & Mean & Std. Dev. & Min. & Max. & N \\
\hline Age in 1984 & 31.48 & 7.36 & 18 & 55 & 453 \\
Non-white & 0.14 & 0.35 & 0 & 1 & 453 \\
High School & 0.11 & 0.31 & 0 & 1 & 453 \\
College & 0.53 & 0.5 & 0 & 1 & 453 \\
Income & 35824.45 & 17595.57 & 5000 & 55000 & 5252 \\
CD4 & 576.72 & 353.86 & 0 & 2915 & 6585 \\
Viral Load & 58245.33 & 255856.98 & 0 & 13060000 & 4148 \\
CES-D Depression Score & 13.31 & 7.7 & 3 & 51 & 6520 \\
Observed Anonymous & 0.74 & 0.44 & 0 & 1 & 453 \\
Alive at Visit 41 & 0.55 & 0.5 & 0 & 1 & 453 \\
Alive at V41 if Post-HAART & 0.83 & 0.38 & 0 & 1 & 268 \\
Celibate in Period t & 0.18 & 0.39 & 0 & 1 & 7224 \\
Monogamous in Period t & 0.24 & 0.43 & 0 & 1 & 7224 \\
Multiple Partners in Period t & 0.58 & 0.49 & 0 & 1 & 7224 \\
\hline
\end{tabular}


Table 5: Basic Results: HIV - and Pre-HAART as Base Category

\begin{tabular}{|c|c|c|c|c|c|c|}
\hline & \multicolumn{6}{|c|}{ Competing RISKS REGRESSION } \\
\hline & (C-MO) & (C-MP) & $(\mathrm{MO}-\mathrm{C})$ & $(\mathrm{MO}-\mathrm{MP})$ & $(\mathrm{MP}-\mathrm{C})$ & $(\mathrm{MP}-\mathrm{MO})$ \\
\hline Post-HAART $\times$ HIV - & $\begin{array}{c}-0.081 \\
(0.132)\end{array}$ & $\begin{array}{c}0.422^{* * *} \\
(0.139)\end{array}$ & $\begin{array}{c}0.064 \\
(0.13)\end{array}$ & $\begin{array}{c}0.237^{* * *} \\
(0.084)\end{array}$ & $\begin{array}{c}-0.044 \\
(0.145)\end{array}$ & $\begin{array}{l}0.2^{* *} \\
(0.087)\end{array}$ \\
\hline Pre-HAART $\times$ HIV + & $\begin{array}{c}-0.078 \\
(1.115)\end{array}$ & $\begin{array}{c}-1.095 \\
(1.418)\end{array}$ & $\begin{array}{c}-0.558 \\
(1.176)\end{array}$ & $\begin{array}{c}-0.542 \\
(0.769)\end{array}$ & $\begin{array}{c}-1.078 \\
(1.397)\end{array}$ & $\begin{array}{c}-1.132 \\
(0.812)\end{array}$ \\
\hline Post-HAART $\times$ HIV + & $\begin{array}{c}0.23 \\
(1.128)\end{array}$ & $\begin{array}{c}-0.444 \\
(1.443)\end{array}$ & $\begin{array}{c}-0.592 \\
(1.185)\end{array}$ & $\begin{array}{c}-0.349 \\
(0.783)\end{array}$ & $\begin{array}{c}-1.239 \\
(1.409)\end{array}$ & $\begin{array}{c}-0.988 \\
(0.815)\end{array}$ \\
\hline Age $\times$ HIV - & $\begin{array}{l}0.016 \\
(0.034)\end{array}$ & $\begin{array}{c}-0.033 \\
(0.046)\end{array}$ & $\begin{array}{c}0.087^{* *} \\
(0.038)\end{array}$ & $\begin{array}{c}-0.058^{* * *} \\
(0.022)\end{array}$ & $\begin{array}{l}0.065 \\
(0.047)\end{array}$ & $\begin{array}{l}0.003 \\
(0.023)\end{array}$ \\
\hline Age squared $\times$ HIV - & $\begin{array}{c}-0.0002 \\
(0.0004)\end{array}$ & $\begin{array}{l}0.0003 \\
(0.0005)\end{array}$ & $\begin{array}{c}-0.0006 \\
(0.0004)\end{array}$ & $\begin{array}{c}0.0005^{* *} \\
(0.0002)\end{array}$ & $\begin{array}{c}-0.0004 \\
(0.0005)\end{array}$ & $\begin{array}{c}-0.00008 \\
(0.0003)\end{array}$ \\
\hline $\mathrm{CD} 4 \times \mathrm{HIV}-$ & $\begin{array}{c}0.141^{* * *} \\
(0.049)\end{array}$ & $\begin{array}{l}0.005 \\
(0.063)\end{array}$ & $\begin{array}{l}0.072 \\
(0.065)\end{array}$ & $\begin{array}{c}0.06 \\
(0.038)\end{array}$ & $\begin{array}{l}0.085 \\
(0.076)\end{array}$ & $\begin{array}{c}0.079^{*} \\
(0.041)\end{array}$ \\
\hline Spell Number $\times$ HIV - & $\begin{array}{c}-0.014 \\
(0.058)\end{array}$ & $\begin{array}{r}-0.12^{*} \\
(0.062)\end{array}$ & $\begin{array}{c}0.022 \\
(0.05)\end{array}$ & $\begin{array}{c}-0.092^{* * *} \\
(0.033)\end{array}$ & $\begin{array}{l}0.11^{*} \\
(0.064)\end{array}$ & $\begin{array}{c}-0.119^{* * *} \\
(0.037)\end{array}$ \\
\hline Anonymous $\times$ HIV- & $\begin{array}{c}-0.316^{* * *} \\
(0.101)\end{array}$ & $\begin{array}{l}0.6^{* * *} \\
(0.132)\end{array}$ & $\begin{array}{c}-0.219^{*} \\
(0.113)\end{array}$ & $\begin{array}{c}0.216^{* * *} \\
(0.07)\end{array}$ & $\begin{array}{c}-0.043 \\
(0.132)\end{array}$ & $\begin{array}{c}-0.277^{* * *} \\
(0.07)\end{array}$ \\
\hline Age $\times$ HIV + & $\begin{array}{l}0.007 \\
(0.038)\end{array}$ & $\begin{array}{c}0.01 \\
(0.049)\end{array}$ & $\begin{array}{c}0.145^{* * *} \\
(0.035)\end{array}$ & $\begin{array}{c}-0.053^{*} \\
(0.03)\end{array}$ & $\begin{array}{c}0.153^{* * *} \\
(0.041)\end{array}$ & $\begin{array}{l}0.048 \\
(0.032)\end{array}$ \\
\hline Age squared $\times \mathrm{HIV}+$ & $\begin{array}{c}-0.0002 \\
(0.0004)\end{array}$ & $\begin{array}{c}-0.0003 \\
(0.0006)\end{array}$ & $\begin{array}{c}-0.001^{* * *} \\
(0.0004)\end{array}$ & $\begin{array}{l}0.0005 \\
(0.0003)\end{array}$ & $\begin{array}{c}-0.001^{* *} \\
(0.0005)\end{array}$ & $\begin{array}{c}-0.0006 \\
(0.0004)\end{array}$ \\
\hline $\mathrm{CD} 4 \times \mathrm{HIV}+$ & $\begin{array}{c}0.207^{* * *} \\
(0.03)\end{array}$ & $\begin{array}{c}0.279^{* * *} \\
(0.038)\end{array}$ & $\begin{array}{l}-0.07 \\
(0.046)\end{array}$ & $\begin{array}{c}0.203^{* * *} \\
(0.029)\end{array}$ & $\begin{array}{c}-0.157^{* * *} \\
(0.055)\end{array}$ & $\begin{array}{c}0.132^{* * *} \\
(0.029)\end{array}$ \\
\hline Spell number $\times$ HIV + & $\begin{array}{l}0.057 \\
(0.052)\end{array}$ & $\begin{array}{c}-0.088 \\
(0.077)\end{array}$ & $\begin{array}{l}0.031 \\
(0.037)\end{array}$ & $\begin{array}{c}-0.035 \\
(0.035)\end{array}$ & $\begin{array}{l}0.017 \\
(0.044)\end{array}$ & $\begin{array}{l}0.014 \\
(0.035)\end{array}$ \\
\hline Anonymous $\times \mathrm{HIV}+$ & $\begin{array}{c}-0.129 \\
(0.082)\end{array}$ & $\begin{array}{l}0.3^{* * *} \\
(0.109)\end{array}$ & $\begin{array}{c}-0.185^{* *} \\
(0.08)\end{array}$ & $\begin{array}{c}0.234^{* * *} \\
(0.073)\end{array}$ & $\begin{array}{l}-0.08 \\
(0.095)\end{array}$ & $\begin{array}{c}-0.356^{* * *} \\
(0.063)\end{array}$ \\
\hline Viral load $(\mathrm{HIV}+)$ & $\begin{array}{l}-0.03 \\
(0.026)\end{array}$ & $\begin{array}{l}0.009 \\
(0.022)\end{array}$ & $\begin{array}{l}0.019 \\
(0.017)\end{array}$ & $\begin{array}{c}-0.006 \\
(0.02)\end{array}$ & $\begin{array}{c}0.038^{* * *} \\
(0.01)\end{array}$ & $\begin{array}{c}-0.008 \\
(0.013)\end{array}$ \\
\hline High school & $\begin{array}{c}0.1 \\
(0.112)\end{array}$ & $\begin{array}{l}0.027 \\
(0.133)\end{array}$ & $\begin{array}{c}0.195^{* *} \\
(0.092)\end{array}$ & $\begin{array}{c}-0.277^{* * *} \\
(0.091)\end{array}$ & $\begin{array}{l}0.043 \\
(0.116)\end{array}$ & $\begin{array}{l}0.003 \\
(0.083)\end{array}$ \\
\hline College degree & $\begin{array}{l}0.102 \\
(0.074)\end{array}$ & $\begin{array}{l}0.131 \\
(0.088)\end{array}$ & $\begin{array}{c}-0.101 \\
(0.075)\end{array}$ & $\begin{array}{c}0.107^{* *} \\
(0.054)\end{array}$ & $\begin{array}{c}-0.142^{*} \\
(0.08)\end{array}$ & $\begin{array}{c}0.15^{* * *} \\
(0.052)\end{array}$ \\
\hline Non-white & $\begin{array}{c}-0.155 \\
(0.095)\end{array}$ & $\begin{array}{l}0.113 \\
(0.107)\end{array}$ & $\begin{array}{c}-0.1 \\
(0.092)\end{array}$ & $\begin{array}{c}0.117^{*} \\
(0.067)\end{array}$ & $\begin{array}{c}-0.136 \\
(0.101)\end{array}$ & $\begin{array}{c}-0.032 \\
(0.061)\end{array}$ \\
\hline CESD-score & $\begin{array}{c}-0.005 \\
(0.003)\end{array}$ & $\begin{array}{l}0.002 \\
(0.004)\end{array}$ & $\begin{array}{l}0.005 \\
(0.003)\end{array}$ & $\begin{array}{l}0.003 \\
(0.003)\end{array}$ & $\begin{array}{c}0.012^{* * *} \\
(0.004)\end{array}$ & $\begin{array}{c}-0.005^{* *} \\
(0.003)\end{array}$ \\
\hline Income & $\begin{array}{l}0.026 \\
(0.017)\end{array}$ & $\begin{array}{c}0.03 \\
(0.021)\end{array}$ & $\begin{array}{c}-0.087^{* * *} \\
(0.016)\end{array}$ & $\begin{array}{c}0.06^{* * *} \\
(0.012)\end{array}$ & $\begin{array}{c}-0.073^{* * *} \\
(0.018)\end{array}$ & $\begin{array}{l}0.015 \\
(0.011)\end{array}$ \\
\hline Observations & 9347 & 9347 & 11770 & 11770 & 24186 & 24186 \\
\hline
\end{tabular}

*** AND ${ }^{* * *}$ INDiCATE SignifiCANCE AT LEVELs 90, 95 AND 99, RESPECTIVELY.

RESUlts ARE COEFFICIENTS. 
Table 6: Basic Results: HIV+ and Pre-HAART as Base Category

\begin{tabular}{|c|c|c|c|c|c|c|}
\hline & \multicolumn{6}{|c|}{ Competing Risks RegREsSion } \\
\hline & (C-MO) & (C-MP) & $(\mathrm{MO}-\mathrm{C})$ & $(\mathrm{MO}-\mathrm{MP})$ & $(\mathrm{MP}-\mathrm{C})$ & $(\mathrm{MP}-\mathrm{MO})$ \\
\hline Pre-HAART $\times$ HIV - & $\begin{array}{l}0.078 \\
(1.115)\end{array}$ & $\begin{array}{l}1.095 \\
(1.418)\end{array}$ & $\begin{array}{l}0.558 \\
(1.176)\end{array}$ & $\begin{array}{l}0.542 \\
(0.769)\end{array}$ & $\begin{array}{l}1.078 \\
(1.397)\end{array}$ & $\begin{array}{l}1.132 \\
(0.812)\end{array}$ \\
\hline Post-HAART $\times$ HIV - & $\begin{array}{c}-0.003 \\
(1.136)\end{array}$ & $\begin{array}{l}1.517 \\
(1.437)\end{array}$ & $\begin{array}{l}0.622 \\
(1.200)\end{array}$ & $\begin{array}{c}0.78 \\
(0.784)\end{array}$ & $\begin{array}{l}1.034 \\
(1.426)\end{array}$ & $\begin{array}{l}1.332 \\
(0.825)\end{array}$ \\
\hline Post-HAART $\times$ HIV + & $\begin{array}{c}0.308^{* * *} \\
(0.101)\end{array}$ & $\begin{array}{c}0.651^{* * *} \\
(0.128)\end{array}$ & $\begin{array}{c}-0.035 \\
(0.09)\end{array}$ & $\begin{array}{c}0.193^{* *} \\
(0.081)\end{array}$ & $\begin{array}{l}-0.16 \\
(0.114)\end{array}$ & $\begin{array}{r}0.144^{*} \\
(0.075)\end{array}$ \\
\hline Age $\times$ HIV - & $\begin{array}{l}0.016 \\
(0.034)\end{array}$ & $\begin{array}{c}-0.033 \\
(0.046)\end{array}$ & $\begin{array}{c}0.087^{* *} \\
(0.038)\end{array}$ & $\begin{array}{c}-0.058^{* * *} \\
(0.022)\end{array}$ & $\begin{array}{l}0.065 \\
(0.047)\end{array}$ & $\begin{array}{l}0.003 \\
(0.023)\end{array}$ \\
\hline Age squared $\times$ HIV - & $\begin{array}{c}-0.0002 \\
(0.0004)\end{array}$ & $\begin{array}{l}0.0003 \\
(0.0005)\end{array}$ & $\begin{array}{c}-0.0006 \\
(0.0004)\end{array}$ & $\begin{array}{c}0.0005^{* *} \\
(0.0002)\end{array}$ & $\begin{array}{c}-0.0004 \\
(0.0005)\end{array}$ & $\begin{array}{c}-0.00008 \\
(0.0003)\end{array}$ \\
\hline $\mathrm{CD} 4 \times \mathrm{HIV}-$ & $\begin{array}{c}0.141^{* * *} \\
(0.049)\end{array}$ & $\begin{array}{l}0.005 \\
(0.063)\end{array}$ & $\begin{array}{l}0.072 \\
(0.065)\end{array}$ & $\begin{array}{c}0.06 \\
(0.038)\end{array}$ & $\begin{array}{l}0.085 \\
(0.076)\end{array}$ & $\begin{array}{c}0.079^{*} \\
(0.041)\end{array}$ \\
\hline Spell Number $\times$ HIV - & $\begin{array}{c}-0.014 \\
(0.058)\end{array}$ & $\begin{array}{r}-0.12^{*} \\
(0.062)\end{array}$ & $\begin{array}{c}0.022 \\
(0.05)\end{array}$ & $\begin{array}{c}-0.092^{* * *} \\
(0.033)\end{array}$ & $\begin{array}{l}0.11^{*} \\
(0.064)\end{array}$ & $\begin{array}{c}-0.119^{* * *} \\
(0.037)\end{array}$ \\
\hline Anonymous $\times$ HIV- & $\begin{array}{c}-0.316^{* * *} \\
(0.101)\end{array}$ & $\begin{array}{l}0.6^{* * *} \\
(0.132)\end{array}$ & $\begin{array}{c}-0.219^{*} \\
(0.113)\end{array}$ & $\begin{array}{c}0.216^{* * *} \\
(0.07)\end{array}$ & $\begin{array}{c}-0.043 \\
(0.132)\end{array}$ & $\begin{array}{c}-0.277^{* * *} \\
(0.07)\end{array}$ \\
\hline Age $\times$ HIV + & $\begin{array}{l}0.007 \\
(0.038)\end{array}$ & $\begin{array}{c}0.01 \\
(0.049)\end{array}$ & $\begin{array}{c}0.145^{* * *} \\
(0.035)\end{array}$ & $\begin{array}{c}-0.053^{*} \\
(0.03)\end{array}$ & $\begin{array}{c}0.153^{* * *} \\
(0.041)\end{array}$ & $\begin{array}{l}0.048 \\
(0.032)\end{array}$ \\
\hline Age squared $\times \mathrm{HIV}+$ & $\begin{array}{c}-0.0002 \\
(0.0004)\end{array}$ & $\begin{array}{c}-0.0003 \\
(0.0006)\end{array}$ & $\begin{array}{c}-0.001^{* * *} \\
(0.0004)\end{array}$ & $\begin{array}{l}0.0005 \\
(0.0003)\end{array}$ & $\begin{array}{c}-0.001^{* *} \\
(0.0005)\end{array}$ & $\begin{array}{c}-0.0006 \\
(0.0004)\end{array}$ \\
\hline $\mathrm{CD} 4 \times \mathrm{HIV}+$ & $\begin{array}{c}0.207^{* * *} \\
(0.03)\end{array}$ & $\begin{array}{c}0.279^{* * *} \\
(0.038)\end{array}$ & $\begin{array}{l}-0.07 \\
(0.046)\end{array}$ & $\begin{array}{c}0.203^{* * *} \\
(0.029)\end{array}$ & $\begin{array}{c}-0.157^{* * *} \\
(0.055)\end{array}$ & $\begin{array}{c}0.132^{* * *} \\
(0.029)\end{array}$ \\
\hline Spell number $\times$ HIV + & $\begin{array}{l}0.057 \\
(0.052)\end{array}$ & $\begin{array}{c}-0.088 \\
(0.077)\end{array}$ & $\begin{array}{l}0.031 \\
(0.037)\end{array}$ & $\begin{array}{c}-0.035 \\
(0.035)\end{array}$ & $\begin{array}{l}0.017 \\
(0.044)\end{array}$ & $\begin{array}{l}0.014 \\
(0.035)\end{array}$ \\
\hline Anonymous $\times \mathrm{HIV}+$ & $\begin{array}{c}-0.129 \\
(0.082)\end{array}$ & $\begin{array}{l}0.3^{* * *} \\
(0.109)\end{array}$ & $\begin{array}{c}-0.185^{* *} \\
(0.08)\end{array}$ & $\begin{array}{c}0.234^{* * *} \\
(0.073)\end{array}$ & $\begin{array}{l}-0.08 \\
(0.095)\end{array}$ & $\begin{array}{c}-0.356^{* * *} \\
(0.063)\end{array}$ \\
\hline Viral load $(\mathrm{HIV}+)$ & $\begin{array}{l}-0.03 \\
(0.026)\end{array}$ & $\begin{array}{l}0.009 \\
(0.022)\end{array}$ & $\begin{array}{l}0.019 \\
(0.017)\end{array}$ & $\begin{array}{c}-0.006 \\
(0.02)\end{array}$ & $\begin{array}{c}0.038^{* * *} \\
(0.01)\end{array}$ & $\begin{array}{c}-0.008 \\
(0.013)\end{array}$ \\
\hline High school & $\begin{array}{c}0.1 \\
(0.112)\end{array}$ & $\begin{array}{l}0.027 \\
(0.133)\end{array}$ & $\begin{array}{c}0.195^{* *} \\
(0.092)\end{array}$ & $\begin{array}{c}-0.277^{* * *} \\
(0.091)\end{array}$ & $\begin{array}{l}0.043 \\
(0.116)\end{array}$ & $\begin{array}{l}0.003 \\
(0.083)\end{array}$ \\
\hline College degree & $\begin{array}{l}0.102 \\
(0.074)\end{array}$ & $\begin{array}{l}0.131 \\
(0.088)\end{array}$ & $\begin{array}{c}-0.101 \\
(0.075)\end{array}$ & $\begin{array}{c}0.107^{* *} \\
(0.054)\end{array}$ & $\begin{array}{c}-0.142^{*} \\
(0.08)\end{array}$ & $\begin{array}{c}0.15^{* * *} \\
(0.052)\end{array}$ \\
\hline Non-white & $\begin{array}{c}-0.155 \\
(0.095)\end{array}$ & $\begin{array}{l}0.113 \\
(0.107)\end{array}$ & $\begin{array}{c}-0.1 \\
(0.092)\end{array}$ & $\begin{array}{c}0.117^{*} \\
(0.067)\end{array}$ & $\begin{array}{c}-0.136 \\
(0.101)\end{array}$ & $\begin{array}{c}-0.032 \\
(0.061)\end{array}$ \\
\hline CESD-score & $\begin{array}{c}-0.005 \\
(0.003)\end{array}$ & $\begin{array}{l}0.002 \\
(0.004)\end{array}$ & $\begin{array}{l}0.005 \\
(0.003)\end{array}$ & $\begin{array}{l}0.003 \\
(0.003)\end{array}$ & $\begin{array}{c}0.012^{* * *} \\
(0.004)\end{array}$ & $\begin{array}{c}-0.005^{* *} \\
(0.003)\end{array}$ \\
\hline Income & $\begin{array}{l}0.026 \\
(0.017)\end{array}$ & $\begin{array}{c}0.03 \\
(0.021)\end{array}$ & $\begin{array}{c}-0.087^{* * *} \\
(0.016)\end{array}$ & $\begin{array}{c}0.06^{* * *} \\
(0.012)\end{array}$ & $\begin{array}{c}-0.073^{* * *} \\
(0.018)\end{array}$ & $\begin{array}{l}0.015 \\
(0.011)\end{array}$ \\
\hline Observations & 9347 & 9347 & 11770 & 11770 & 24186 & 24186 \\
\hline
\end{tabular}

*** AND $^{* * *}$ INDiCATE SignifiCANCE AT LEVELs 90, 95 AND 99, RESPECTIVELY.

RESUltS ARE COEFFICIENTS. 
Table 7: Monogamy to Multiple Partners

\begin{tabular}{|c|c|c|c|c|}
\hline & \multicolumn{4}{|c|}{ "Competing Risks RegRession } \\
\hline & 1 & 2 & 3 & 4 \\
\hline Pre-HAART $\times$ HIV - & . & . & $\begin{array}{l}0.542 \\
(0.769)\end{array}$ & $\begin{array}{l}0.489 \\
(0.769)\end{array}$ \\
\hline Post-HAART $\times$ HIV - & $\begin{array}{c}0.237^{* * *} \\
(0.084)\end{array}$ & $\begin{array}{l}0.047 \\
(0.095)\end{array}$ & $\begin{array}{c}0.78 \\
(0.784)\end{array}$ & $\begin{array}{l}0.536 \\
(0.785)\end{array}$ \\
\hline Pre-HAART $\times$ HIV + & $\begin{array}{c}-0.542 \\
(0.769)\end{array}$ & $\begin{array}{c}-0.489 \\
(0.769)\end{array}$ & . & \\
\hline Post-HAART $\times \mathrm{HIV}+$ & $\begin{array}{c}-0.349 \\
(0.783)\end{array}$ & $\begin{array}{c}-0.584 \\
(0.782)\end{array}$ & $\begin{array}{c}0.193^{* *} \\
(0.081)\end{array}$ & $\begin{array}{c}-0.096 \\
(0.099)\end{array}$ \\
\hline Age $\times$ HIV - & $\begin{array}{c}-0.058^{* * *} \\
(0.022)\end{array}$ & $\begin{array}{c}-0.059^{* * *} \\
(0.022)\end{array}$ & $\begin{array}{c}-0.058^{* * *} \\
(0.022)\end{array}$ & $\begin{array}{c}-0.059^{* * *} \\
(0.022)\end{array}$ \\
\hline $\mathrm{CD} 4 \times \mathrm{HIV}-$ & $\begin{array}{c}0.06 \\
(0.038)\end{array}$ & $\begin{array}{l}0.061 \\
(0.038)\end{array}$ & $\begin{array}{c}0.06 \\
(0.038)\end{array}$ & $\begin{array}{l}0.061 \\
(0.038)\end{array}$ \\
\hline Spell Number $\times$ HIV - & $\begin{array}{c}-0.092^{* * *} \\
(0.033)\end{array}$ & $\begin{array}{c}-0.091^{* * *} \\
(0.034)\end{array}$ & $\begin{array}{c}-0.092^{* * *} \\
(0.033)\end{array}$ & $\begin{array}{c}-0.091^{* * *} \\
(0.034)\end{array}$ \\
\hline Anonymous $\times$ HIV- & $\begin{array}{c}0.216^{* * *} \\
(0.07)\end{array}$ & $\begin{array}{c}0.219^{* * *} \\
(0.071)\end{array}$ & $\begin{array}{c}0.216^{* * *} \\
(0.07)\end{array}$ & $\begin{array}{c}0.219^{* * *} \\
(0.071)\end{array}$ \\
\hline Age $\times \mathrm{HIV}+$ & $\begin{array}{c}-0.053^{*} \\
(0.03)\end{array}$ & $\begin{array}{c}-0.048 \\
(0.03)\end{array}$ & $\begin{array}{c}-0.053^{*} \\
(0.03)\end{array}$ & $\begin{array}{c}-0.048 \\
(0.03)\end{array}$ \\
\hline $\mathrm{CD} 4 \times \mathrm{HIV}+$ & $\begin{array}{c}0.203^{* * *} \\
(0.029)\end{array}$ & $\begin{array}{c}0.199^{* * *} \\
(0.029)\end{array}$ & $\begin{array}{c}0.203^{* * *} \\
(0.029)\end{array}$ & $\begin{array}{c}0.199^{* * *} \\
(0.029)\end{array}$ \\
\hline Spell number $\times$ HIV + & $\begin{array}{c}-0.035 \\
(0.035)\end{array}$ & $\begin{array}{r}-0.037 \\
(0.035)\end{array}$ & $\begin{array}{c}-0.035 \\
(0.035)\end{array}$ & $\begin{array}{r}-0.037 \\
(0.035)\end{array}$ \\
\hline Anonymous $\times \mathrm{HIV}+$ & $\begin{array}{c}0.234^{* * *} \\
(0.073)\end{array}$ & $\begin{array}{c}0.231^{* * *} \\
(0.072)\end{array}$ & $\begin{array}{c}0.234^{* * *} \\
(0.073)\end{array}$ & $\begin{array}{c}0.231^{* * *} \\
(0.072)\end{array}$ \\
\hline Viral load $(\mathrm{HIV}+)$ & $\begin{array}{l}-0.006 \\
(0.02)\end{array}$ & $\begin{array}{c}-0.006 \\
(0.021)\end{array}$ & $\begin{array}{c}-0.006 \\
(0.02)\end{array}$ & $\begin{array}{c}-0.006 \\
(0.021)\end{array}$ \\
\hline Pre-HAART $\times$ HIV $-\times$ Spell-length & . & . & . & $\begin{array}{l}0.099^{* * *} \\
(0.033)\end{array}$ \\
\hline Post-HAART $\times$ HIV $-\times$ Spell-length & . & $\begin{array}{l}0.091^{* * *} \\
(0.025)\end{array}$ & . & $\begin{array}{l}0.189^{* * *} \\
(0.034)\end{array}$ \\
\hline Pre-HAART $\times$ HIV $+\times$ Spell-length & . & $\begin{array}{c}-0.099^{* * *} \\
(0.033)\end{array}$ & . & . \\
\hline Post-HAART $\times$ HIV $+\times$ Spell-length & . & $\begin{array}{c}0.056^{* *} \\
(0.027)\end{array}$ & . & $\begin{array}{l}0.154^{* * *} \\
\quad(0.034)\end{array}$ \\
\hline Observations & 11770 & 11770 & 11770 & 11770 \\
\hline
\end{tabular}

*** AND $^{* * *}$ INDICATE SIGNIFICANCE AT LEVELS 90, 95 AND 99, RESPECTIVELY.

RESUlts ARE COEFFICIENTS. 
Table 8: Multiple Partners to Monogamy

\begin{tabular}{|c|c|c|c|c|}
\hline & \multicolumn{4}{|c|}{ COMPETING Risks REGRESSION } \\
\hline & 1 & 2 & 3 & 4 \\
\hline Pre-HAART $\times$ HIV - & . & & $\begin{array}{l}1.132 \\
(0.812)\end{array}$ & $\begin{array}{c}1.116 \\
(0.81)\end{array}$ \\
\hline Post-HAART $\times$ HIV - & $\begin{array}{l}0.2^{* *} \\
(0.087)\end{array}$ & $\begin{array}{c}-0.19^{*} \\
(0.102)\end{array}$ & $\begin{array}{l}1.332 \\
(0.825)\end{array}$ & $\begin{array}{l}0.927 \\
(0.821)\end{array}$ \\
\hline Pre-HAART $\times$ HIV + & $\begin{array}{c}-1.132 \\
(0.812)\end{array}$ & $\begin{array}{c}-1.116 \\
(0.81)\end{array}$ & . & . \\
\hline Post-HAART $\times \mathrm{HIV}+$ & $\begin{array}{c}-0.988 \\
(0.815)\end{array}$ & $\begin{array}{c}-1.155 \\
(0.812)\end{array}$ & $\begin{array}{r}0.144^{*} \\
(0.075)\end{array}$ & $\begin{array}{c}-0.038 \\
(0.09)\end{array}$ \\
\hline Age $\times$ HIV - & $\begin{array}{l}0.003 \\
(0.023)\end{array}$ & $\begin{array}{l}0.007 \\
(0.023)\end{array}$ & $\begin{array}{l}0.003 \\
(0.023)\end{array}$ & $\begin{array}{l}0.007 \\
(0.023)\end{array}$ \\
\hline $\mathrm{CD} 4 \times \mathrm{HIV}-$ & $\begin{array}{c}0.079^{*} \\
(0.041)\end{array}$ & $\begin{array}{c}0.081^{* *} \\
(0.041)\end{array}$ & $\begin{array}{r}0.079^{*} \\
(0.041)\end{array}$ & $\begin{array}{c}0.081^{* *} \\
(0.041)\end{array}$ \\
\hline Spell Number $\times$ HIV- & $\begin{array}{c}-0.119^{* * *} \\
(0.037)\end{array}$ & $\begin{array}{c}-0.111^{* * *} \\
(0.037)\end{array}$ & $\begin{array}{c}-0.119^{* * *} \\
(0.037)\end{array}$ & $\begin{array}{c}-0.111^{* * *} \\
(0.037)\end{array}$ \\
\hline Anonymous $\times$ HIV- & $\begin{array}{c}-0.277^{* * *} \\
(0.07)\end{array}$ & $\begin{array}{c}-0.287^{* * *} \\
(0.07)\end{array}$ & $\begin{array}{c}-0.277^{* * *} \\
(0.07)\end{array}$ & $\begin{array}{c}-0.287^{* * *} \\
(0.07)\end{array}$ \\
\hline Age $\times \mathrm{HIV}+$ & $\begin{array}{l}0.048 \\
(0.032)\end{array}$ & $\begin{array}{l}0.051 \\
(0.032)\end{array}$ & $\begin{array}{l}0.048 \\
(0.032)\end{array}$ & $\begin{array}{l}0.051 \\
(0.032)\end{array}$ \\
\hline $\mathrm{CD} 4 \times \mathrm{HIV}+$ & $\begin{array}{c}0.132^{* * *} \\
(0.029)\end{array}$ & $\begin{array}{c}0.131^{* * *} \\
(0.029)\end{array}$ & $\begin{array}{c}0.132^{* * *} \\
(0.029)\end{array}$ & $\begin{array}{c}0.131^{* * *} \\
(0.029)\end{array}$ \\
\hline Spell number $\times \mathrm{HIV}+$ & $\begin{array}{l}0.014 \\
(0.035)\end{array}$ & $\begin{array}{c}0.01 \\
(0.035)\end{array}$ & $\begin{array}{l}0.014 \\
(0.035)\end{array}$ & $\begin{array}{c}0.01 \\
(0.035)\end{array}$ \\
\hline Anonymous $\times \mathrm{HIV}+$ & $\begin{array}{c}-0.356^{* * *} \\
(0.063)\end{array}$ & $\begin{array}{l}-0.353^{* * *} \\
(0.062)\end{array}$ & $\begin{array}{l}-0.356^{* * *} \\
\quad(0.063)\end{array}$ & $\begin{array}{l}-0.353^{* * *} \\
\quad(0.062)\end{array}$ \\
\hline Viral load $(\mathrm{HIV}+)$ & $\begin{array}{c}-0.008 \\
(0.013)\end{array}$ & $\begin{array}{c}-0.007 \\
(0.013)\end{array}$ & $\begin{array}{c}-0.008 \\
(0.013)\end{array}$ & $\begin{array}{c}-0.007 \\
(0.013)\end{array}$ \\
\hline Pre-HAART $\times$ HIV $-\times$ Spell-length & . & . & . & $\begin{array}{l}0.003 \\
(0.015)\end{array}$ \\
\hline Post-HAART $\times$ HIV $-\times$ Spell-length & . & $\begin{array}{l}0.109^{* * *} \\
(0.015)\end{array}$ & . & $\begin{array}{l}0.111^{* * *} \\
(0.014)\end{array}$ \\
\hline Pre-HAART $\times$ HIV $+\times$ Spell-length & . & $\begin{array}{c}-0.003 \\
(0.015)\end{array}$ & . & . \\
\hline Post-HAART $\times$ HIV $+\times$ Spell-length & . & $\begin{array}{c}0.06^{* * *} \\
(0.016)\end{array}$ & . & $\begin{array}{c}0.062^{* * *} \\
(0.016)\end{array}$ \\
\hline Observations & 24186 & 24186 & 24186 & 24186 \\
\hline
\end{tabular}

$*, * *$ AND ${ }^{* * *}$ INDICATE SIGNIFICANCE AT LEVELS 90, 95 AND 99, RESPECTIVELY.

RESUlts ARE COEFFICIENTS. 
Table 9: Re-Partnering

\begin{tabular}{|c|c|c|}
\hline & COMPETING RISKS & REGRESSION \\
\hline & 1 & 2 \\
\hline Post-HAART $\times$ HIV $-\times$ Celibate at 1996 & $\begin{array}{l}0.319 \\
(0.247)\end{array}$ & . \\
\hline Post-HAART $\times$ HIV $-\times$ Monogamous at 1996 & $\begin{array}{c}0.389^{* * *} \\
(0.132)\end{array}$ & . \\
\hline Post-HAART $\times$ HIV $-\times$ Mult. Part. at 1996 & $\begin{array}{c}0.197^{* *} \\
(0.099)\end{array}$ & . \\
\hline Post-HAART $\times$ HIV $-\times$ Unobserved at 1996 & $\begin{array}{c}-0.279^{*} \\
(0.149)\end{array}$ & . \\
\hline $\mathrm{CD} 4 \times \mathrm{HIV}-$ & $\begin{array}{c}0.127^{* * *} \\
(0.038)\end{array}$ & . \\
\hline Post-HAART $\times$ HIV $+\times$ Celibate at 1996 & $\cdot$ & $\begin{array}{c}-0.063 \\
(0.172)\end{array}$ \\
\hline Post-HAART $\times$ HIV $+\times$ Monogamous at 1996 & . & $\begin{array}{c}0.234^{* *} \\
(0.119)\end{array}$ \\
\hline Post-HAART $\times$ HIV $+\times$ Mult. Part. at 1996 & . & $\begin{array}{l}0.018 \\
(0.089)\end{array}$ \\
\hline Post-HAART $\times$ HIV $+\times$ Unobserved at 1996 & . & $\begin{array}{c}-0.185 \\
(0.136)\end{array}$ \\
\hline $\mathrm{CD} 4 \times \mathrm{HIV}+$ & . & $\begin{array}{l}0.094^{* * *} \\
(0.029)\end{array}$ \\
\hline Age & $\begin{array}{l}0.003 \\
(0.024)\end{array}$ & $\begin{array}{l}0.048 \\
(0.031)\end{array}$ \\
\hline Age Squared & $\begin{array}{c}-0.00006 \\
(0.0003)\end{array}$ & $\begin{array}{c}-0.0006 \\
(0.0004)\end{array}$ \\
\hline Spell & $\begin{array}{c}-0.094^{* * *} \\
(0.035)\end{array}$ & $\begin{array}{c}-0.005 \\
(0.036)\end{array}$ \\
\hline Observed Anonymous & $\begin{array}{c}-0.341^{* * *} \\
\quad(0.069)\end{array}$ & $\begin{array}{l}-0.353^{* * *} \\
(0.061)\end{array}$ \\
\hline Observations & 12050 & 12136 \\
\hline
\end{tabular}

$*{ }^{* *}$ AND ${ }^{* * *}$ INDICATE SIGNIFICANCE AT LEVELS 90, 95 AND 99, RESPECTIVELY.

RESUlts ARE COEFFICIENTS. 
Table 10: Summary Statistics: Subsample for Repartnering Analysis

\begin{tabular}{lccccc}
\hline \multicolumn{1}{c}{ Variable } & Mean & Std. Dev. & Min. & Max. & N \\
\hline Age in 1984 & 32.75 & 7.45 & 18 & 70 & 2054 \\
Non-white & 0.18 & 0.39 & 0 & 1 & 2054 \\
High School & 0.11 & 0.31 & 0 & 1 & 2054 \\
College & 0.59 & 0.49 & 0 & 1 & 2054 \\
Income & 37922.13 & 17002.68 & 5000 & 55000 & 19455 \\
\% Observed Anonymous & 0.65 & 0.48 & 0 & 1 & 2054 \\
\% HIV+at Baseline & 0.4 & 0.49 & 0 & 1 & 2054 \\
\% HIV- at Visit 41 & 0.45 & 0.5 & 0 & 1 & 2054 \\
\% Observed Seroconverter & 0.16 & 0.36 & 0 & 1 & 2054 \\
\hline
\end{tabular}

Table 11: CES-D Scale: HIV+

\begin{tabular}{|c|c|c|c|c|c|}
\hline & \multicolumn{5}{|c|}{ COMPETING RISKS REGRESSION } \\
\hline & 1 & 2 & 3 & 4 & 5 \\
\hline Post-HAART & $\begin{array}{c}-0.297^{*} \\
(0.167)\end{array}$ & $\begin{array}{c}-0.732^{* *} \\
(0.33)\end{array}$ & $\begin{array}{c}-0.682^{* *} \\
(0.334)\end{array}$ & . & . \\
\hline Post-HAART $\times$ Monog. at 1996 & . & . & . & $\begin{array}{c}-0.384 \\
(0.456)\end{array}$ & $\begin{array}{c}-0.227 \\
(0.474)\end{array}$ \\
\hline Post-HAART × Monog. at 1996 × Gap & . & . & . & . & $\begin{array}{c}-0.795 \\
(0.658)\end{array}$ \\
\hline Pre-HAART $\times$ Celibate at 1996 & . & . & . & $\begin{array}{c}0.914^{* *} \\
(0.429)\end{array}$ & $\begin{array}{c}0.886^{* *} \\
(0.43)\end{array}$ \\
\hline Post-HAART $\times$ Celibate at 1996 & . & . & . & $\begin{array}{l}0.283 \\
(0.518)\end{array}$ & $\begin{array}{l}0.217 \\
(0.521)\end{array}$ \\
\hline Pre-HAART × Mult. Part. at 1996 & . & . & 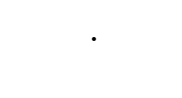 & $\begin{array}{l}0.14 \\
(0.36)\end{array}$ & $\begin{array}{l}0.073 \\
(0.364)\end{array}$ \\
\hline Post-HAART $\times$ Mult. Part. at 1996 & . & . & . & $\begin{array}{c}-0.673 \\
(0.458)\end{array}$ & $\begin{array}{c}-0.797^{*} \\
(0.469)\end{array}$ \\
\hline Age & . & $\begin{array}{c}-0.002 \\
(0.435)\end{array}$ & $\begin{array}{c}-0.039 \\
(0.442)\end{array}$ & $\begin{array}{l}0.017 \\
(0.452)\end{array}$ & $\begin{array}{l}0.088 \\
(0.456)\end{array}$ \\
\hline Age-Squared & . & $\begin{array}{l}0.002 \\
(0.005)\end{array}$ & $\begin{array}{l}0.002 \\
(0.005)\end{array}$ & $\begin{array}{l}0.001 \\
(0.005)\end{array}$ & $\begin{array}{c}0.0009 \\
(0.005)\end{array}$ \\
\hline CD4 (Mean Centered) & . & . & $\begin{array}{c}-0.906^{* * *} \\
(0.248)\end{array}$ & $\begin{array}{c}-0.89^{* * *} \\
(0.249)\end{array}$ & $\begin{array}{l}-0.887^{* * *} \\
\quad(0.249)\end{array}$ \\
\hline Observations & 3670 & 3670 & 3597 & 3597 & 3597 \\
\hline
\end{tabular}

${ }^{*},{ }^{* *}$ AND $^{* * *}$ INDICATE SIGNIFICANCE AT LEVELS 90, 95 AND 99, RESPECTIVELY.

RESUlts ARE COEFFICIENTS. 
Table 12: CES-D Scale: HIV-

\begin{tabular}{|c|c|c|c|c|c|}
\hline & \multicolumn{5}{|c|}{ "COMPETING RISKS REGRESSION } \\
\hline & 1 & 2 & 3 & 4 & 5 \\
\hline Post-HAART & $\begin{array}{l}-0.11 \\
(0.182)\end{array}$ & $\begin{array}{l}0.228 \\
(0.365)\end{array}$ & $\begin{array}{l}0.154 \\
(0.367)\end{array}$ & . & . \\
\hline Post-HAART $\times$ Monog. at 1996 & . & . & . & $\begin{array}{c}-0.125 \\
(0.495)\end{array}$ & $\begin{array}{c}-0.005 \\
(0.509)\end{array}$ \\
\hline Post-HAART $\times$ Monog. at $1996 \times$ Gap & . & . & . & . & $\begin{array}{c}-0.743 \\
(0.728)\end{array}$ \\
\hline Pre-HAART $\times$ Celibate at 1996 & . & . & . & $\begin{array}{c}-0.202 \\
(0.577)\end{array}$ & $\begin{array}{l}-0.221 \\
(0.578)\end{array}$ \\
\hline Post-HAART $\times$ Celibate at 1996 & . & . & . & $\begin{array}{l}0.407 \\
(0.633)\end{array}$ & $\begin{array}{l}0.336 \\
(0.637)\end{array}$ \\
\hline Pre-HAART × Mult. Part. at 1996 & . & . & . & $\begin{array}{c}-0.037 \\
(0.418)\end{array}$ & $\begin{array}{c}-0.122 \\
(0.427)\end{array}$ \\
\hline Post-HAART × Mult. Part. at 1996 & . & . & . & $\begin{array}{c}0.132 \\
(0.52)\end{array}$ & $\begin{array}{c}-0.006 \\
(0.537)\end{array}$ \\
\hline Age & . & $\begin{array}{l}0.044 \\
(0.384)\end{array}$ & $\begin{array}{c}-0.254 \\
(0.41)\end{array}$ & $\begin{array}{c}-0.234 \\
(0.412)\end{array}$ & $\begin{array}{c}-0.216 \\
(0.413)\end{array}$ \\
\hline Age-Squared & . & $\begin{array}{c}-0.002 \\
(0.004)\end{array}$ & $\begin{array}{l}0.001 \\
(0.004)\end{array}$ & $\begin{array}{l}0.001 \\
(0.004)\end{array}$ & $\begin{array}{l}0.001 \\
(0.004)\end{array}$ \\
\hline CD4 (Mean Centered) & . & . & $\begin{array}{c}-0.666^{* *} \\
(0.264)\end{array}$ & $\begin{array}{c}-0.66^{* *} \\
(0.264)\end{array}$ & $\begin{array}{c}-0.652^{* *} \\
(0.265)\end{array}$ \\
\hline Observations & 3095 & 3095 & 2540 & 2540 & 2540 \\
\hline
\end{tabular}

$*,{ }^{* *}$ AND $^{* * *}$ INDICATE SIGNIFICANCE AT LEVELS 90, 95 AND 99, RESPECTIVELY.

RESULTS ARE COEFFICIENTS. 
Figure 1: HIV - and Celibate

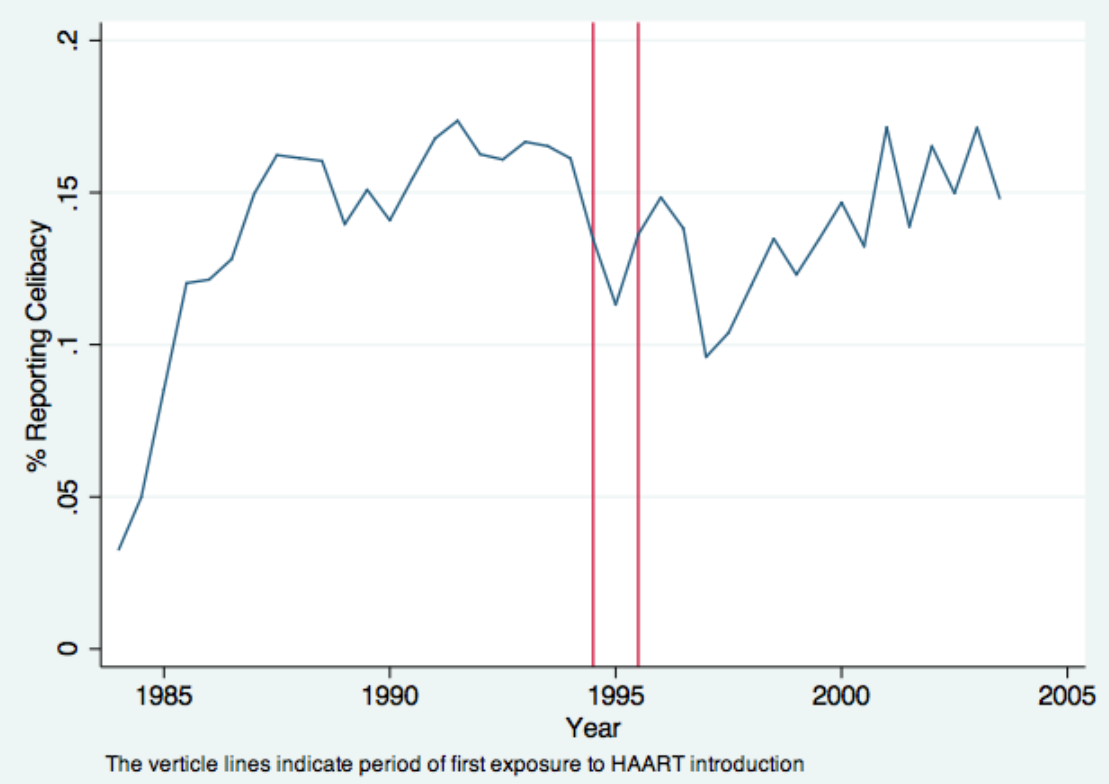

Figure 2: HIV - and Monogamous

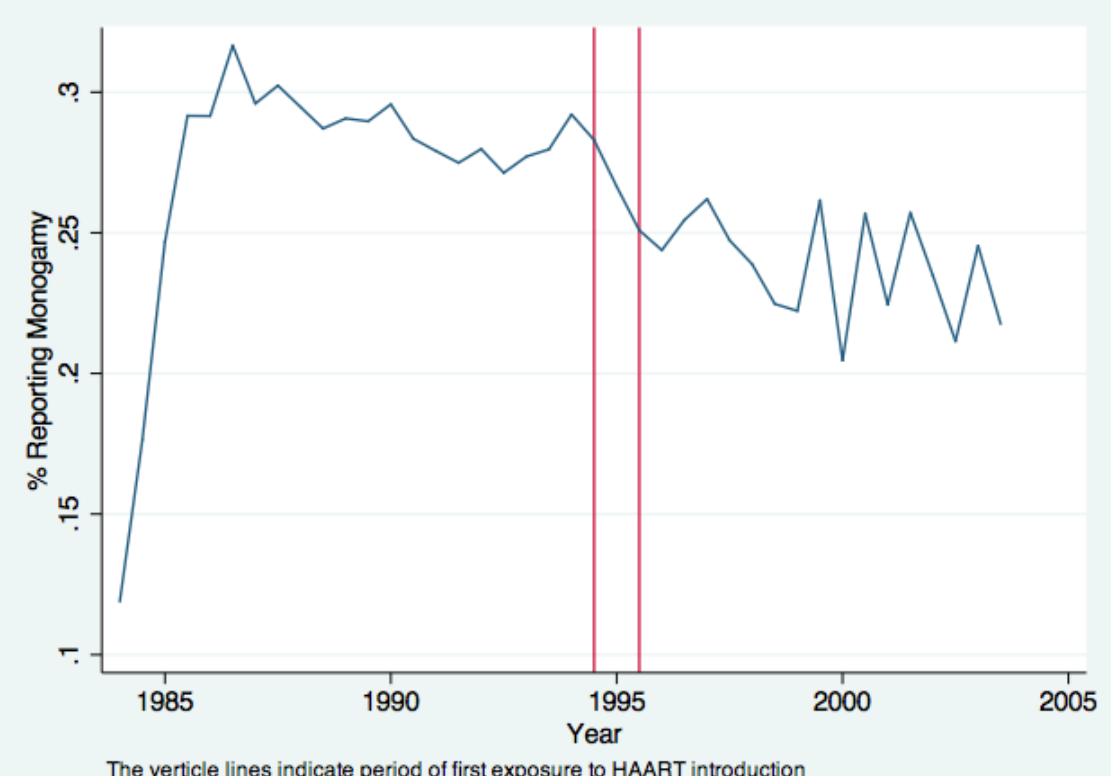


Figure 3: HIV - and Multiple Partners

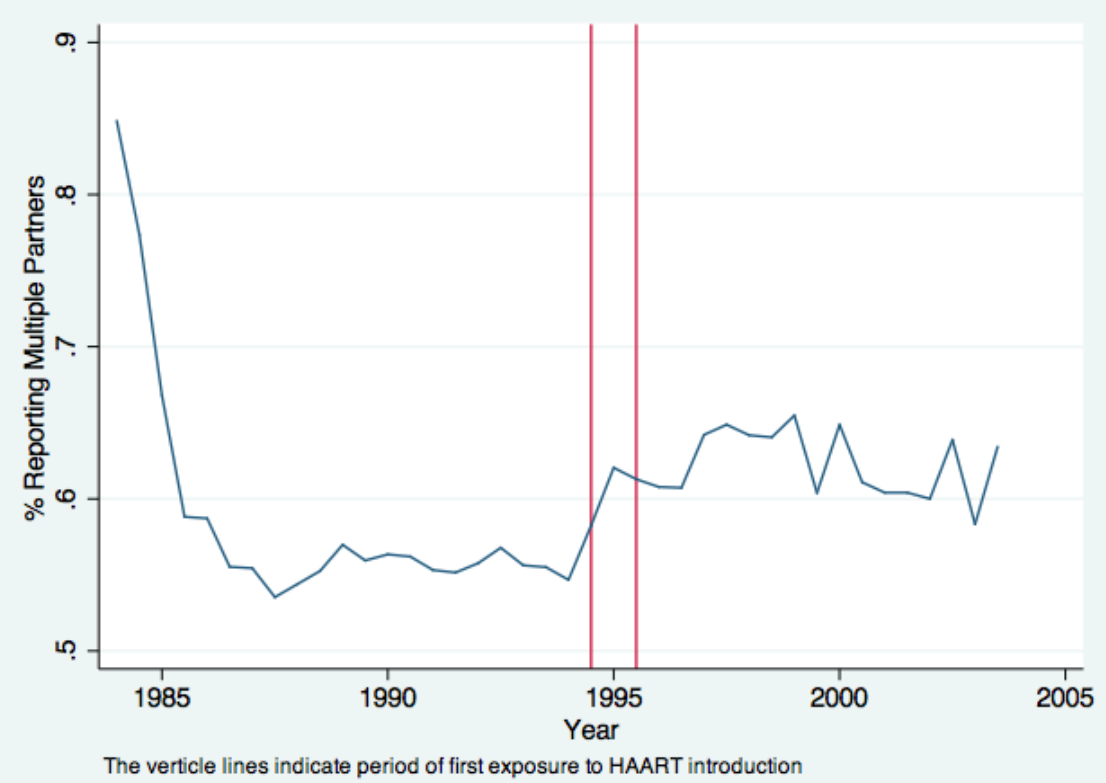

Figure 4: HIV+ and Celibate

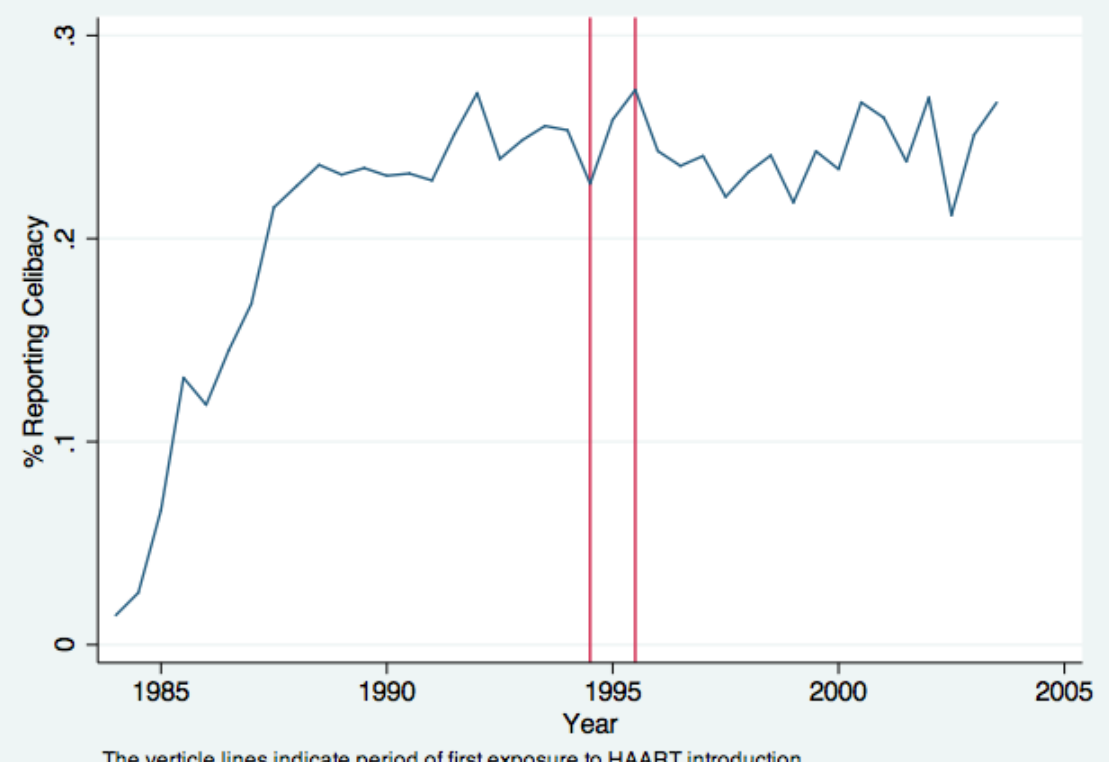


Figure 5: HIV+ and Monogamous

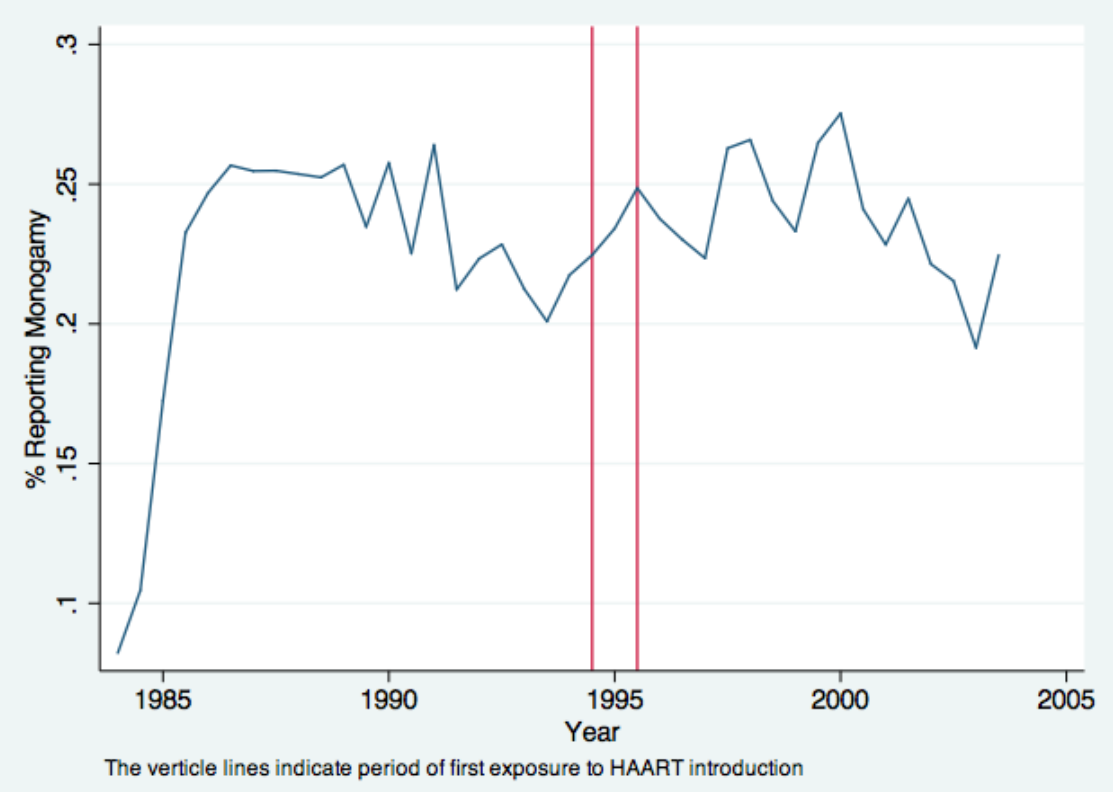

Figure 6: HIV+ and Multiple Partners

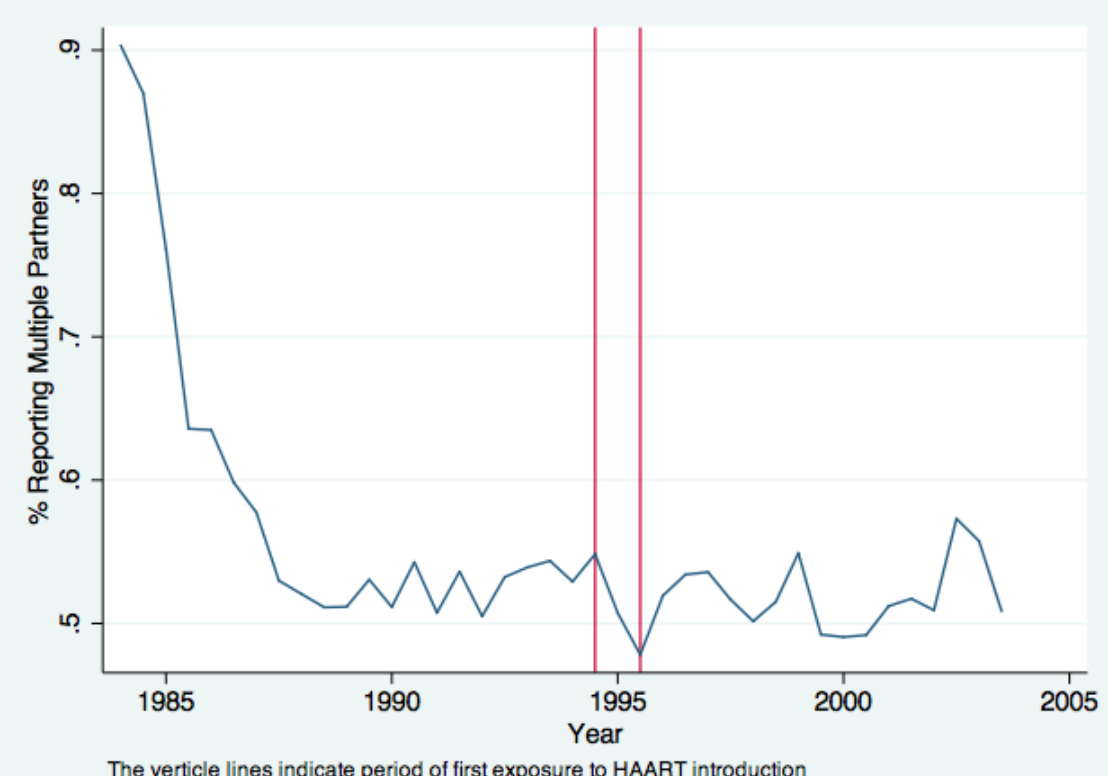




\section{Appendix}

This appendix contains results on a number of specification and robustness checks. As a baseline model, I use the competing risks regression where the dependent variable is time until exit from monogamy and the destination of interest is multiple partners. Competing risks are death, celibacy and attrition. In each of the following tables, the first column presents results from the baseline model, equivalent to results found in Column (1) of Table 7. In all cases, main results hold.

Table A.1 contains results from robustness checks concerning attrition and sample constructions. In Columns (2)-(5), models contain the following modifications over the baseline model: (2) attrition is not a competing risk; (3) being censored is treated as a competing risk; (4) being censored or spell ending due to missing visits are treated as competing risks; (5) and a stronger precautrion regarding possibly administrative censored HIVsubjects is used.

Table A.2 contains results from robustness checks concerning the sex variable used in analysis. In Columns (2)-(6), models contain the following modifications over the baseline model: (2) a shorter sample is used (visits 15-27) where full partnership information is available; (3) the same subsample is used but monogamy is now defined as intercourse with a partner who is not anonymous and who is also monogamous; (4) All sex activity is allowed in counting partners; (5) Anal sex only is used in counting partners; (6) I allow for gaps of up to one year of celibacy in spells of monogamy.

Table A.3 contains results from robustness checks concerning spell construction. In Columns (2)-(3), models contain the following modifications over the baseline model: (2) spells that begin before 1991 and that are ongoing in 1991 are included; (3) up to two visits may be skipped without a spell being broken.

Tables A.4 and A.5 contain results from robustness checks concerning the econometric model. In Columns (2)-(3) of Table A.4 models contain the following modifications over 
the baseline model: (2) I do not use the variable counting previous spells; (3): I use actual CD4 count rather than CD4 count at spell begin. In Table A.5, modifications are (2) I use a proportional hazards model that treats all spells that end in a destination other than multiple partners as randomly censored; (3) I use only spells that are not left censored; (4) all non-HAART-era variables are interacted with the left-censor dummy.

I also use limited data on reported partnership length (available for a limited number of periods after HAART introduction) to compare reported partnership length with constructed partnership length. Figure A.1 presents a scatter plot of these two measures, showing that higher constructed lengths are associated with higher reported lengths. Differences are stongest for long reported partnerships, perhaps due to missing visits or other gaps. On the other hand, reported partnership lengths often do not reasonably follow the passage of time, exhibiting jumps in partnership length that are much more than the visit-to-visit half year. 
Table A.1: Robustness Checks: Attrition and Sample Construction

\begin{tabular}{|c|c|c|c|c|c|}
\hline & \multicolumn{5}{|c|}{ Competing Risks Regression } \\
\hline & 1 & 2 & 3 & 4 & 5 \\
\hline Post-HAART $\times$ HIV- & $\begin{array}{c}0.237^{* * *} \\
(0.084)\end{array}$ & $\begin{array}{l}0.21^{* *} \\
(0.084)\end{array}$ & $\begin{array}{c}0.232^{* * *} \\
(0.085)\end{array}$ & $\begin{array}{c}0.241^{* * *} \\
(0.085)\end{array}$ & $\begin{array}{c}0.155^{*} \\
(0.086)\end{array}$ \\
\hline Pre-HAART $\times$ HIV + & $\begin{array}{c}-0.542 \\
(0.769)\end{array}$ & $\begin{array}{c}-0.545 \\
(0.77)\end{array}$ & $\begin{array}{c}-0.791 \\
(0.782)\end{array}$ & $\begin{array}{c}-0.826 \\
(0.783)\end{array}$ & $\begin{array}{c}-0.155 \\
(0.801)\end{array}$ \\
\hline Post-HAART $\times$ HIV + & $\begin{array}{c}-0.349 \\
(0.783)\end{array}$ & $\begin{array}{c}-0.334 \\
(0.783)\end{array}$ & $\begin{array}{c}-0.652 \\
(0.794)\end{array}$ & $\begin{array}{c}-0.685 \\
(0.795)\end{array}$ & $\begin{array}{l}0.031 \\
(0.814)\end{array}$ \\
\hline Age $\times$ HIV - & $\begin{array}{c}-0.058^{* * *} \\
(0.022)\end{array}$ & $\begin{array}{c}-0.061^{* * *} \\
(0.022)\end{array}$ & $\begin{array}{c}-0.057^{* * *} \\
\quad(0.022)\end{array}$ & $\begin{array}{c}-0.057^{* * *} \\
(0.022)\end{array}$ & $\begin{array}{c}-0.036 \\
(0.024)\end{array}$ \\
\hline Age squared $\times$ HIV - & $\begin{array}{c}0.0005^{* *} \\
(0.0002)\end{array}$ & $\begin{array}{c}0.0005^{* *} \\
(0.0002)\end{array}$ & $\begin{array}{c}0.0005^{* *} \\
(0.0002)\end{array}$ & $\begin{array}{c}0.0005^{* *} \\
(0.0002)\end{array}$ & $\begin{array}{l}0.0002 \\
(0.0003)\end{array}$ \\
\hline $\mathrm{CD} 4 \times \mathrm{HIV}-$ & $\begin{array}{c}0.06 \\
(0.038)\end{array}$ & $\begin{array}{l}0.062 \\
(0.038)\end{array}$ & $\begin{array}{l}0.061 \\
(0.039)\end{array}$ & $\begin{array}{c}0.065^{*} \\
(0.039)\end{array}$ & $\begin{array}{l}0.006 \\
(0.041)\end{array}$ \\
\hline Spell Number $\times$ HIV- & $\begin{array}{c}-0.092^{* * *} \\
(0.033)\end{array}$ & $\begin{array}{c}-0.085^{* *} \\
(0.033)\end{array}$ & $\begin{array}{c}-0.099^{* * *} \\
(0.034)\end{array}$ & $\begin{array}{c}-0.103^{* * *} \\
(0.034)\end{array}$ & $\begin{array}{c}-0.096^{* * *} \\
(0.035)\end{array}$ \\
\hline Observed Anonymous $\times$ HIV- & $\begin{array}{c}0.216^{* * *} \\
(0.07)\end{array}$ & $\begin{array}{c}0.208^{* * *} \\
(0.069)\end{array}$ & $\begin{array}{c}0.204^{* * *} \\
(0.071)\end{array}$ & $\begin{array}{c}0.205^{* * *} \\
(0.071)\end{array}$ & $\begin{array}{c}0.229^{* * *} \\
(0.077)\end{array}$ \\
\hline Age $\times \mathrm{HIV}+$ & $\begin{array}{c}-0.053^{*} \\
(0.03)\end{array}$ & $\begin{array}{c}-0.057^{*} \\
(0.03)\end{array}$ & $\begin{array}{c}-0.039 \\
(0.03)\end{array}$ & $\begin{array}{c}-0.038 \\
(0.03)\end{array}$ & $\begin{array}{c}-0.055^{*} \\
(0.03)\end{array}$ \\
\hline Age squared $\times \mathrm{HIV}+$ & $\begin{array}{c}0.0005 \\
(0.0003)\end{array}$ & $\begin{array}{l}0.0005 \\
(0.0004)\end{array}$ & $\begin{array}{l}0.0003 \\
(0.0004)\end{array}$ & $\begin{array}{c}0.0003 \\
(0.0004)\end{array}$ & $\begin{array}{l}0.0005 \\
(0.0004)\end{array}$ \\
\hline $\mathrm{CD} 4 \times \mathrm{HIV}+$ & $\begin{array}{c}0.203^{* * *} \\
(0.029)\end{array}$ & $\begin{array}{c}0.204^{* * *} \\
(0.029)\end{array}$ & $\begin{array}{c}0.196^{* * *} \\
(0.029)\end{array}$ & $\begin{array}{c}0.199^{* * *} \\
(0.029)\end{array}$ & $\begin{array}{c}0.207^{* * *} \\
(0.03)\end{array}$ \\
\hline Spell number $\times$ HIV + & $\begin{array}{c}-0.035 \\
(0.035)\end{array}$ & $\begin{array}{l}-0.03 \\
(0.035)\end{array}$ & $\begin{array}{c}-0.041 \\
(0.035)\end{array}$ & $\begin{array}{c}-0.042 \\
(0.035)\end{array}$ & $\begin{array}{c}-0.037 \\
(0.035)\end{array}$ \\
\hline Observed Anonymous $\times \mathrm{HIV}+$ & $\begin{array}{c}0.234^{* * *} \\
(0.073)\end{array}$ & $\begin{array}{c}0.24^{* * *} \\
(0.073)\end{array}$ & $\begin{array}{c}0.217^{\text {*** }} \\
(0.073)\end{array}$ & $\begin{array}{c}0.22^{* * *} \\
(0.073)\end{array}$ & $\begin{array}{c}0.234^{* * *} \\
(0.073)\end{array}$ \\
\hline Viral load $(\mathrm{HIV}+)$ & $\begin{array}{c}-0.006 \\
(0.02)\end{array}$ & $\begin{array}{c}-0.005 \\
(0.021)\end{array}$ & $\begin{array}{c}-0.011 \\
(0.021)\end{array}$ & $\begin{array}{c}-0.014 \\
(0.021)\end{array}$ & $\begin{array}{c}-0.008 \\
(0.022)\end{array}$ \\
\hline High school & $\begin{array}{c}-0.277^{* * *} \\
(0.091)\end{array}$ & $\begin{array}{c}-0.28^{* * *} \\
(0.091)\end{array}$ & $\begin{array}{c}-0.281^{* * *} \\
(0.094)\end{array}$ & $\begin{array}{c}-0.28^{* * *} \\
(0.094)\end{array}$ & $\begin{array}{c}-0.298^{* * *} \\
(0.094)\end{array}$ \\
\hline College degree & $\begin{array}{c}0.107^{* *} \\
(0.054)\end{array}$ & $\begin{array}{c}0.094^{*} \\
(0.054)\end{array}$ & $\begin{array}{c}0.122^{* *} \\
(0.054)\end{array}$ & $\begin{array}{c}0.123^{* *} \\
(0.054)\end{array}$ & $\begin{array}{c}0.113^{* *} \\
(0.055)\end{array}$ \\
\hline Non-white & $\begin{array}{c}0.117^{*} \\
(0.067)\end{array}$ & $\begin{array}{c}0.123^{*} \\
(0.067)\end{array}$ & $\begin{array}{l}0.098 \\
(0.068)\end{array}$ & $\begin{array}{l}0.098 \\
(0.068)\end{array}$ & $\begin{array}{c}0.109 \\
(0.07)\end{array}$ \\
\hline CESD-score & $\begin{array}{l}0.003 \\
(0.003)\end{array}$ & $\begin{array}{l}0.003 \\
(0.003)\end{array}$ & $\begin{array}{l}0.003 \\
(0.003)\end{array}$ & $\begin{array}{l}0.003 \\
(0.003)\end{array}$ & $\begin{array}{l}0.004 \\
(0.003)\end{array}$ \\
\hline Income & $\begin{array}{c}0.06^{* * *} \\
(0.012)\end{array}$ & $\begin{array}{c}0.064^{* * *} \\
(0.012)\end{array}$ & $\begin{array}{c}0.049^{* * *} \\
(0.012)\end{array}$ & $\begin{array}{c}0.048^{* * *} \\
(0.012)\end{array}$ & $\begin{array}{c}0.059^{* * *} \\
(0.012)\end{array}$ \\
\hline Observations & 11770 & 11770 & 11770 & 11770 & 10848 \\
\hline
\end{tabular}

${ }^{*},{ }^{* *}$ AND ${ }^{* * *}$ INDICATE SIGNIFICANCE AT LEVELS 90, 95 AND 99, RESPECTIVELY.

RESUlts ARE COEFFICIENTS. 
Table A.2: Robustness Checks: Sex Variable

\begin{tabular}{|c|c|c|c|c|c|c|}
\hline & \multicolumn{5}{|c|}{ Competing Risks RegREssion } & \multirow[b]{2}{*}{6} \\
\hline & 1 & 2 & 3 & 4 & 5 & \\
\hline Post-HAART $\times$ HIV - & $\begin{array}{c}0.237^{* * *} \\
(0.084)\end{array}$ & $\begin{array}{c}0.493^{* * *} \\
(0.164)\end{array}$ & $\begin{array}{c}0.564^{* * *} \\
(0.201)\end{array}$ & $\begin{array}{c}0.226^{* * *} \\
(0.078)\end{array}$ & $\begin{array}{c}0.389^{* * *} \\
(0.117)\end{array}$ & $\begin{array}{c}0.207^{* *} \\
(0.085)\end{array}$ \\
\hline Pre-HAART $\times$ HIV + & $\begin{array}{c}-0.542 \\
(0.769)\end{array}$ & $\begin{array}{l}-0.988 \\
(1.412)\end{array}$ & $\begin{array}{c}-0.346 \\
(0.221)\end{array}$ & $\begin{array}{c}-0.487 \\
(0.695)\end{array}$ & $\begin{array}{c}-0.442 \\
(1.146)\end{array}$ & $\begin{array}{c}-0.806 \\
(0.748)\end{array}$ \\
\hline Post-HAART $\times$ HIV + & $\begin{array}{c}-0.349 \\
(0.783)\end{array}$ & $\begin{array}{c}-0.696 \\
(1.424)\end{array}$ & $\begin{array}{c}-0.632^{* *} \\
(0.29)\end{array}$ & $\begin{array}{c}-0.278 \\
(0.707)\end{array}$ & $\begin{array}{l}-0.2 \\
(1.159)\end{array}$ & $\begin{array}{c}-0.591 \\
(0.761)\end{array}$ \\
\hline Age $\times \mathrm{HIV}-$ & $\begin{array}{c}-0.058^{* * *} \\
(0.022)\end{array}$ & $\begin{array}{c}-0.029 \\
(0.04)\end{array}$ & $\begin{array}{c}0.05 \\
(0.046)\end{array}$ & $\begin{array}{c}-0.043^{* *} \\
(0.02)\end{array}$ & $\begin{array}{c}-0.012 \\
(0.038)\end{array}$ & $\begin{array}{c}-0.059^{* * *} \\
(0.021)\end{array}$ \\
\hline Age squared $\times$ HIV- & $\begin{array}{c}0.0005^{* *} \\
(0.0002)\end{array}$ & $\begin{array}{c}0.00008 \\
(0.0004)\end{array}$ & $\begin{array}{c}-0.0007 \\
(0.0005)\end{array}$ & $\begin{array}{c}0.0003 \\
(0.0002)\end{array}$ & $\begin{array}{c}-0.0001 \\
(0.0004)\end{array}$ & $\begin{array}{c}0.0005^{* *} \\
(0.0002)\end{array}$ \\
\hline $\mathrm{CD} 4 \times \mathrm{HIV}-$ & $\begin{array}{c}0.06 \\
(0.038)\end{array}$ & $\begin{array}{l}0.066 \\
(0.056)\end{array}$ & $\begin{array}{c}0.119^{*} \\
(0.069)\end{array}$ & $\begin{array}{l}0.053 \\
(0.033)\end{array}$ & $\begin{array}{l}0.017 \\
(0.053)\end{array}$ & $\begin{array}{l}0.037 \\
(0.037)\end{array}$ \\
\hline Spell Number $\times$ HIV - & $\begin{array}{c}-0.092^{* * *} \\
(0.033)\end{array}$ & $\begin{array}{c}-0.31^{* * *} \\
(0.076)\end{array}$ & $\begin{array}{c}-0.309^{* * *} \\
(0.101)\end{array}$ & $\begin{array}{c}-0.066^{*} \\
(0.034)\end{array}$ & $\begin{array}{c}-0.058 \\
(0.054)\end{array}$ & $\begin{array}{c}-0.049 \\
(0.038)\end{array}$ \\
\hline Observed Anonymous $\times$ HIV- & $\begin{array}{c}0.216^{* * *} \\
\quad(0.07)\end{array}$ & $\begin{array}{l}0.061 \\
(0.102)\end{array}$ & $\begin{array}{c}-0.003 \\
(0.127)\end{array}$ & $\begin{array}{c}0.136^{* *} \\
(0.063)\end{array}$ & $\begin{array}{l}0.065 \\
(0.099)\end{array}$ & $\begin{array}{c}0.18^{* * *} \\
(0.068)\end{array}$ \\
\hline Age $\times \mathrm{HIV}+$ & $\begin{array}{c}-0.053^{*} \\
(0.03)\end{array}$ & $\begin{array}{l}-0.025 \\
(0.056)\end{array}$ & $\begin{array}{l}0.043 \\
(0.048)\end{array}$ & $\begin{array}{c}-0.036 \\
(0.027)\end{array}$ & $\begin{array}{l}-0.01 \\
(0.042)\end{array}$ & $\begin{array}{c}-0.045 \\
(0.029)\end{array}$ \\
\hline Age squared $\times \mathrm{HIV}+$ & $\begin{array}{l}0.0005 \\
(0.0003)\end{array}$ & $\begin{array}{l}0.0002 \\
(0.0007)\end{array}$ & $\begin{array}{c}-0.0006 \\
(0.0006)\end{array}$ & $\begin{array}{l}0.0003 \\
(0.0003)\end{array}$ & $\begin{array}{l}-4.68 \mathrm{e}-06 \\
(0.0005)\end{array}$ & $\begin{array}{l}0.0004 \\
(0.0003)\end{array}$ \\
\hline $\mathrm{CD} 4 \times \mathrm{HIV}+$ & $\begin{array}{c}0.203^{* * *} \\
(0.029)\end{array}$ & $\begin{array}{c}0.226^{* * *} \\
(0.039)\end{array}$ & $\begin{array}{c}0.153^{* * *} \\
(0.048)\end{array}$ & $\begin{array}{c}0.221^{* * *} \\
(0.025)\end{array}$ & $\begin{array}{c}0.168^{* * *} \\
(0.035)\end{array}$ & $\begin{array}{c}0.235^{* * *} \\
(0.026)\end{array}$ \\
\hline Spell number $\times$ HIV + & $\begin{array}{c}-0.035 \\
(0.035)\end{array}$ & $\begin{array}{l}0.013 \\
(0.065)\end{array}$ & $\begin{array}{l}0.004 \\
(0.082)\end{array}$ & $\begin{array}{c}-0.038 \\
(0.032)\end{array}$ & $\begin{array}{c}-0.037 \\
(0.039)\end{array}$ & $\begin{array}{l}0.034 \\
(0.035)\end{array}$ \\
\hline Observed Anonymous $\times \mathrm{HIV}+$ & $\begin{array}{l}0.234^{* * *} \\
(0.073)\end{array}$ & $\begin{array}{c}0.216^{* *} \\
(0.099)\end{array}$ & $\begin{array}{c}0.288^{* *} \\
(0.121)\end{array}$ & $\begin{array}{c}0.149^{* *} \\
(0.063)\end{array}$ & $\begin{array}{l}0.144 \\
(0.089)\end{array}$ & $\begin{array}{l}0.218^{* * *} \\
(0.068)\end{array}$ \\
\hline Viral load $(\mathrm{HIV}+)$ & $\begin{array}{c}-0.006 \\
(0.02)\end{array}$ & $\begin{array}{c}0.01 \\
(0.026)\end{array}$ & $\begin{array}{c}-0.026 \\
(0.035)\end{array}$ & $\begin{array}{l}-0.008 \\
(0.02)\end{array}$ & $\begin{array}{c}-0.007 \\
(0.024)\end{array}$ & $\begin{array}{c}-0.006 \\
(0.022)\end{array}$ \\
\hline High school & $\begin{array}{c}-0.277^{* * *} \\
(0.091)\end{array}$ & $\begin{array}{c}-0.229^{*} \\
(0.124)\end{array}$ & $\begin{array}{c}-0.312^{*} \\
(0.17)\end{array}$ & $\begin{array}{c}-0.256^{* * *} \\
(0.085)\end{array}$ & $\begin{array}{c}-0.292^{* *} \\
(0.123)\end{array}$ & $\begin{array}{c}-0.238^{* * *} \\
(0.09)\end{array}$ \\
\hline College degree & $\begin{array}{c}0.107^{* *} \\
(0.054)\end{array}$ & $\begin{array}{c}-0.075 \\
(0.081)\end{array}$ & $\begin{array}{c}-0.044 \\
(0.104)\end{array}$ & $\begin{array}{c}0.137^{* * *} \\
(0.049)\end{array}$ & $\begin{array}{c}0.091 \\
(0.07)\end{array}$ & $\begin{array}{c}0.118^{* *} \\
(0.051)\end{array}$ \\
\hline Non-white & $\begin{array}{c}0.117^{*} \\
(0.067)\end{array}$ & $\begin{array}{l}0.099 \\
(0.089)\end{array}$ & $\begin{array}{l}0.121 \\
(0.115)\end{array}$ & $\begin{array}{c}0.134^{* *} \\
(0.06)\end{array}$ & $\begin{array}{c}0.254^{* * *} \\
(0.082)\end{array}$ & $\begin{array}{c}0.1 \\
(0.064)\end{array}$ \\
\hline CESD-score & $\begin{array}{l}0.003 \\
(0.003)\end{array}$ & $\begin{array}{c}0.008^{* *} \\
(0.004)\end{array}$ & $\begin{array}{l}0.001 \\
(0.006)\end{array}$ & $\begin{array}{l}0.001 \\
(0.003)\end{array}$ & $\begin{array}{l}0.006 \\
(0.004)\end{array}$ & $\begin{array}{l}0.002 \\
(0.003)\end{array}$ \\
\hline Income & $\begin{array}{c}0.06^{* * *} \\
(0.012)\end{array}$ & $\begin{array}{c}0.074^{* * *} \\
(0.022)\end{array}$ & $\begin{array}{l}0.039 \\
(0.026)\end{array}$ & $\begin{array}{c}0.049^{* * *} \\
(0.011)\end{array}$ & $\begin{array}{c}0.046^{* * *} \\
(0.017)\end{array}$ & $\begin{array}{c}0.057^{* * *} \\
(0.012)\end{array}$ \\
\hline Observations & 11770 & 4948 & 3349 & 12073 & 7945 & 12640 \\
\hline
\end{tabular}

*,** AND ${ }^{* * *}$ INDICATE SIGNIFICANCE AT LEVELS 90, 95 AND 99, RESPECTIVELY.

RESUltS ARE COEFFICIENTS. 
Table A.3: Robustness Checks: Sex Spell Construction

\begin{tabular}{|c|c|c|c|}
\hline & \multicolumn{3}{|c|}{ Competing Risks Regression } \\
\hline & 1 & 2 & 3 \\
\hline Post-HAART $\times$ HIV - & $\begin{array}{c}0.237^{* * *} \\
(0.084)\end{array}$ & $\begin{array}{c}0.223^{* * *} \\
(0.084)\end{array}$ & $\begin{array}{c}0.387^{* * *} \\
(0.098)\end{array}$ \\
\hline Pre-HAART $\times$ HIV + & $\begin{array}{c}-0.542 \\
(0.769)\end{array}$ & $\begin{array}{c}-0.498 \\
(0.774)\end{array}$ & $\begin{array}{c}-0.986 \\
(0.746)\end{array}$ \\
\hline Post-HAART $\times$ HIV + & $\begin{array}{c}-0.349 \\
(0.783)\end{array}$ & $\begin{array}{c}-0.301 \\
(0.787)\end{array}$ & $\begin{array}{c}-0.819 \\
(0.761)\end{array}$ \\
\hline Age $\times$ HIV - & $\begin{array}{c}-0.058^{* * *} \\
(0.022)\end{array}$ & $\begin{array}{c}-0.049^{* *} \\
(0.022)\end{array}$ & $\begin{array}{c}-0.046^{* *} \\
(0.022)\end{array}$ \\
\hline Age squared $\times$ HIV - & $\begin{array}{c}0.0005^{* *} \\
(0.0002)\end{array}$ & $\begin{array}{l}0.0004 \\
(0.0002)\end{array}$ & $\begin{array}{l}0.0003 \\
(0.0003)\end{array}$ \\
\hline $\mathrm{CD} 4 \times \mathrm{HIV}-$ & $\begin{array}{c}0.06 \\
(0.038)\end{array}$ & $\begin{array}{l}0.045 \\
(0.036)\end{array}$ & $\begin{array}{c}0.02 \\
(0.037)\end{array}$ \\
\hline Spell Number $\times$ HIV - & $\begin{array}{c}-0.092^{* * *} \\
\quad(0.033)\end{array}$ & $\begin{array}{c}-0.099^{* * *} \\
(0.034)\end{array}$ & $\begin{array}{l}-0.243^{* * *} \\
\quad(0.067)\end{array}$ \\
\hline Anonymous $\times$ HIV- & $\begin{array}{c}0.216^{* * *} \\
(0.07)\end{array}$ & $\begin{array}{l}0.207^{* * *} \\
\quad(0.071)\end{array}$ & $\begin{array}{l}0.185^{* * *} \\
\quad(0.068)\end{array}$ \\
\hline Age $\times \mathrm{HIV}+$ & $\begin{array}{c}-0.053^{*} \\
(0.03)\end{array}$ & $\begin{array}{c}-0.048 \\
(0.03)\end{array}$ & $\begin{array}{c}-0.036 \\
(0.028)\end{array}$ \\
\hline Age squared $\times \mathrm{HIV}+$ & $\begin{array}{l}0.0005 \\
(0.0003)\end{array}$ & $\begin{array}{l}0.0004 \\
(0.0004)\end{array}$ & $\begin{array}{c}0.0003 \\
(0.0003)\end{array}$ \\
\hline $\mathrm{CD} 4 \times \mathrm{HIV}+$ & $\begin{array}{c}0.203^{* * *} \\
(0.029)\end{array}$ & $\begin{array}{c}0.2^{* * *} \\
(0.03)\end{array}$ & $\begin{array}{l}0.219^{* * *} \\
(0.028)\end{array}$ \\
\hline Spell number $\times$ HIV+ & $\begin{array}{c}-0.035 \\
(0.035)\end{array}$ & $\begin{array}{c}-0.035 \\
(0.036)\end{array}$ & $\begin{array}{c}-0.047 \\
(0.06)\end{array}$ \\
\hline Anonymous $\times \mathrm{HIV}+$ & $\begin{array}{c}0.234^{* * *} \\
(0.073)\end{array}$ & $\begin{array}{c}0.234^{* * *} \\
(0.073)\end{array}$ & $\begin{array}{l}0.2^{* * *} \\
(0.069)\end{array}$ \\
\hline Viral load $(\mathrm{HIV}+)$ & $\begin{array}{c}-0.006 \\
(0.02)\end{array}$ & $\begin{array}{c}-0.007 \\
(0.02)\end{array}$ & $\begin{array}{c}-0.022 \\
(0.023)\end{array}$ \\
\hline High school & $\begin{array}{c}-0.277^{* * *} \\
(0.091)\end{array}$ & $\begin{array}{c}-0.276^{* * *} \\
(0.091)\end{array}$ & $\begin{array}{c}-0.229^{* * *} \\
(0.085)\end{array}$ \\
\hline College degree & $\begin{array}{c}0.107^{* *} \\
(0.054)\end{array}$ & $\begin{array}{c}0.1^{*} \\
(0.054)\end{array}$ & $\begin{array}{c}0.133^{* *} \\
(0.052)\end{array}$ \\
\hline Non-white & $\begin{array}{c}0.117^{*} \\
(0.067)\end{array}$ & $\begin{array}{c}0.126^{*} \\
(0.068)\end{array}$ & $\begin{array}{c}0.132^{* *} \\
(0.061)\end{array}$ \\
\hline CESD-score & $\begin{array}{l}0.003 \\
(0.003)\end{array}$ & $\begin{array}{l}0.004 \\
(0.003)\end{array}$ & $\begin{array}{l}0.001 \\
(0.003)\end{array}$ \\
\hline Income & $\begin{array}{c}0.06^{* * *} \\
(0.012)\end{array}$ & $\begin{array}{c}0.059^{* * *} \\
(0.012)\end{array}$ & $\begin{array}{c}0.038^{* * *} \\
(0.012)\end{array}$ \\
\hline Observations & 11770 & 12576 & 9165 \\
\hline
\end{tabular}

*,** AND ${ }^{* * *}$ INDICATE SIGNIFICANCE AT LEVELS 90, 95 AND 99, RESPECTIVELY.

RESUlts ARE COEFFICIENTS. 
Table A.4: Robustness Checks: Econometric Model I

\begin{tabular}{|c|c|c|c|}
\hline & \multicolumn{3}{|c|}{ COMPETING RISKS REGRESSION } \\
\hline & 1 & 2 & 3 \\
\hline Post-HAART $\times$ HIV - & $\begin{array}{c}0.237^{* * *} \\
(0.084)\end{array}$ & $\begin{array}{c}0.175^{* *} \\
(0.08)\end{array}$ & $\begin{array}{l}0.172^{*} \\
(0.095)\end{array}$ \\
\hline Pre-HAART $\times$ HIV + & $\begin{array}{l}-0.542 \\
(0.769)\end{array}$ & $\begin{array}{l}-0.495 \\
(0.766)\end{array}$ & $\begin{array}{l}-0.057 \\
(0.833)\end{array}$ \\
\hline Post-HAART $\times$ HIV + & $\begin{array}{r}-0.349 \\
(0.783)\end{array}$ & $\begin{array}{l}-0.324 \\
(0.781)\end{array}$ & $\begin{array}{l}-0.217 \\
(0.828)\end{array}$ \\
\hline Age $\times \mathrm{HIV}-$ & $\begin{array}{c}-0.058^{* * *} \\
(0.022)\end{array}$ & $\begin{array}{c}-0.063^{* * *} \\
(0.021)\end{array}$ & $\begin{array}{c}-0.045^{* *} \\
(0.022)\end{array}$ \\
\hline Age squared $\times$ HIV - & $\begin{array}{c}0.0005^{* *} \\
(0.0002)\end{array}$ & $\begin{array}{c}0.0005^{* *} \\
(0.0002)\end{array}$ & $\begin{array}{l}0.0004 \\
(0.0002)\end{array}$ \\
\hline $\mathrm{CD} 4 \times \mathrm{HIV}-$ & $\begin{array}{c}0.06 \\
(0.038)\end{array}$ & $\begin{array}{l}0.072^{*} \\
(0.037)\end{array}$ & . \\
\hline Actual CD4 HIV- & . & . & $\begin{array}{l}-0.0005 \\
(0.0004)\end{array}$ \\
\hline Actual CD4 Squared HIV- & . & . & $\begin{array}{l}1.02 \mathrm{e}-07 \\
(1.65 \mathrm{e}-07)\end{array}$ \\
\hline Spell Number $\times$ HIV - & $\begin{array}{c}-0.092^{* * *} \\
(0.033)\end{array}$ & . & $\begin{array}{r}-0.049 \\
(0.034)\end{array}$ \\
\hline Anonymous $\times$ HIV- & $\begin{array}{l}0.216^{* * *} \\
(0.07)\end{array}$ & $\begin{array}{l}0.218^{* * *} \\
\quad(0.07)\end{array}$ & $\begin{array}{c}0.235^{* * *} \\
(0.074)\end{array}$ \\
\hline Age $\times \mathrm{HIV}+$ & $\begin{array}{c}-0.053^{*} \\
(0.03)\end{array}$ & $\begin{array}{c}-0.055^{*} \\
(0.03)\end{array}$ & $\begin{array}{c}-0.072^{* *} \\
(0.03)\end{array}$ \\
\hline Age squared $\times \mathrm{HIV}+$ & $\begin{array}{l}0.0005 \\
(0.0003)\end{array}$ & $\begin{array}{l}0.0005 \\
(0.0003)\end{array}$ & $\begin{array}{l}0.0006^{*} \\
(0.0004)\end{array}$ \\
\hline $\mathrm{CD} 4 \times \mathrm{HIV}+$ & $\begin{array}{c}0.203^{* * *} \\
(0.029)\end{array}$ & $\begin{array}{c}0.204^{* * *} \\
(0.029)\end{array}$ & \\
\hline Actual CD4 HIV+ & . & . & $\begin{array}{c}0.003^{* * *} \\
(0.0004)\end{array}$ \\
\hline Actual CD4 Squared HIV+ & . & . & $\begin{array}{l}-1.53 \mathrm{e}-06^{* * *} \\
(3.24 \mathrm{e}-07)\end{array}$ \\
\hline Spell number $\times$ HIV + & $\begin{array}{l}-0.035 \\
(0.035)\end{array}$ & . & $\begin{array}{c}-0.083^{* *} \\
(0.04)\end{array}$ \\
\hline Anonymous $\times$ HIV + & $\begin{array}{c}0.234^{* * *} \\
(0.073)\end{array}$ & $\begin{array}{c}0.237^{* * *} \\
(0.073)\end{array}$ & $\begin{array}{c}0.253^{* * *} \\
(0.072)\end{array}$ \\
\hline Viral load (HIV+) & $\begin{array}{c}-0.006 \\
(0.02)\end{array}$ & $\begin{array}{c}-0.006 \\
(0.02)\end{array}$ & $\begin{array}{l}0.018 \\
(0.02)\end{array}$ \\
\hline High school & $\begin{array}{c}-0.277^{* * *} \\
(0.091)\end{array}$ & $\begin{array}{c}-0.277^{* * *} \\
(0.091)\end{array}$ & $\begin{array}{c}-0.249^{* * *} \\
(0.092)\end{array}$ \\
\hline College degree & $\begin{array}{c}0.107^{* *} \\
(0.054)\end{array}$ & $\begin{array}{c}0.111^{* *} \\
(0.054)\end{array}$ & $\begin{array}{c}0.118^{* *} \\
(0.055)\end{array}$ \\
\hline Non-white & $\begin{array}{l}0.117^{*} \\
(0.067)\end{array}$ & $\begin{array}{l}0.115^{*} \\
(0.067)\end{array}$ & $\begin{array}{l}0.068 \\
(0.068)\end{array}$ \\
\hline CESD-score & $\begin{array}{l}0.003 \\
(0.003)\end{array}$ & $\begin{array}{l}0.003 \\
(0.003)\end{array}$ & $\begin{array}{c}0.002 \\
(0.003)\end{array}$ \\
\hline Income & $\begin{array}{c}0.06^{* * *} \\
(0.012)\end{array}$ & $\begin{array}{c}0.055^{* * *} \\
(0.012)\end{array}$ & $\begin{array}{c}0.05^{* * *} \\
(0.013)\end{array}$ \\
\hline Observations & 11770 & 11770 & 10323 \\
\hline
\end{tabular}

*,** AND ${ }^{* * *}$ INDICATE SIGNIFICANCE AT LEVELS 90, 95 AND 99, RESPECTIVELY.

Results ARE COEFFICIENTS. 
Table A.5: Robustness Checks: Econometric Model II

\begin{tabular}{|c|c|c|c|c|}
\hline & \multicolumn{4}{|c|}{ COMPETING Risks REGRESSION } \\
\hline & 1 & 2 & 3 & 4 \\
\hline Post-HAART $\times$ HIV - & $\begin{array}{c}0.237^{* * *} \\
(0.084)\end{array}$ & . & $\begin{array}{c}0.218^{* *} \\
(0.087)\end{array}$ & $\begin{array}{c}0.241^{* * *} \\
(0.083)\end{array}$ \\
\hline Pre-HAART $\times$ HIV + & $\begin{array}{c}-0.542 \\
(0.769)\end{array}$ & . & $\begin{array}{c}-0.787 \\
(0.837)\end{array}$ & $\begin{array}{c}-0.491 \\
(0.773)\end{array}$ \\
\hline Post-HAART $\times \mathrm{HIV}+$ & $\begin{array}{c}-0.349 \\
(0.783)\end{array}$ & . & $\begin{array}{c}-0.569 \\
(0.851)\end{array}$ & $\begin{array}{c}-0.302 \\
(0.786)\end{array}$ \\
\hline Age $\times$ HIV - & $\begin{array}{c}-0.058^{* * *} \\
(0.022)\end{array}$ & $\begin{array}{c}-0.049^{* * *} \\
(0.016)\end{array}$ & $\begin{array}{c}-0.06^{* * *} \\
(0.023)\end{array}$ & $\begin{array}{c}-0.058^{* * *} \\
(0.022)\end{array}$ \\
\hline Age squared $\times$ HIV- & $\begin{array}{c}0.0005^{* *} \\
(0.0002)\end{array}$ & $\begin{array}{c}0.0004^{* *} \\
(0.0002)\end{array}$ & $\begin{array}{c}0.0005^{* *} \\
(0.0002)\end{array}$ & $\begin{array}{c}0.0005^{* *} \\
(0.0002)\end{array}$ \\
\hline $\mathrm{CD} 4 \times \mathrm{HIV}-$ & $\begin{array}{c}0.06 \\
(0.038)\end{array}$ & $\begin{array}{c}0.073^{* *} \\
(0.035)\end{array}$ & $\begin{array}{c}0.09^{* *} \\
(0.04)\end{array}$ & $\begin{array}{c}0.087^{* *} \\
(0.039)\end{array}$ \\
\hline Spell Number $\times$ HIV- & $\begin{array}{c}-0.092^{* * *} \\
(0.033)\end{array}$ & $\begin{array}{c}-0.032 \\
(0.029)\end{array}$ & $\begin{array}{c}-0.073^{* *} \\
(0.034)\end{array}$ & $\begin{array}{c}-0.075^{* *} \\
(0.034)\end{array}$ \\
\hline Age $\times \mathrm{HIV}+$ & $\begin{array}{c}-0.053^{*} \\
(0.03)\end{array}$ & $\begin{array}{c}-0.064^{* * *} \\
(0.017)\end{array}$ & $\begin{array}{l}-0.04 \\
(0.033)\end{array}$ & $\begin{array}{c}-0.053^{*} \\
(0.03)\end{array}$ \\
\hline Age squared $\times \mathrm{HIV}+$ & $\begin{array}{l}0.0005 \\
(0.0003)\end{array}$ & $\begin{array}{c}0.0007^{* * *} \\
(0.0002)\end{array}$ & $\begin{array}{c}0.0003 \\
(0.0004)\end{array}$ & $\begin{array}{c}0.0005 \\
(0.0004)\end{array}$ \\
\hline $\mathrm{CD} 4 \times \mathrm{HIV}+$ & $\begin{array}{c}0.203^{* * *} \\
(0.029)\end{array}$ & $\begin{array}{c}0.163^{* * *} \\
(0.028)\end{array}$ & $\begin{array}{c}0.205^{* * *} \\
(0.031)\end{array}$ & $\begin{array}{c}0.208^{* * *} \\
(0.03)\end{array}$ \\
\hline Spell number $\times$ HIV + & $\begin{array}{c}-0.035 \\
(0.035)\end{array}$ & $\begin{array}{l}0.036 \\
(0.034)\end{array}$ & $\begin{array}{c}-0.028 \\
(0.036)\end{array}$ & $\begin{array}{c}-0.023 \\
(0.036)\end{array}$ \\
\hline Viral load $(\mathrm{HIV}+)$ & $\begin{array}{c}-0.006 \\
(0.02)\end{array}$ & $\begin{array}{l}0.04^{* *} \\
(0.018)\end{array}$ & $\begin{array}{c}-0.003 \\
(0.021)\end{array}$ & $\begin{array}{c}-0.004 \\
(0.021)\end{array}$ \\
\hline High school & $\begin{array}{c}-0.277^{* * *} \\
(0.091)\end{array}$ & $\begin{array}{c}-0.258^{* * *} \\
(0.086)\end{array}$ & $\begin{array}{c}-0.25^{* * *} \\
(0.096)\end{array}$ & $\begin{array}{c}-0.25^{* * *} \\
(0.095)\end{array}$ \\
\hline College degree & $\begin{array}{c}0.107^{* *} \\
(0.054)\end{array}$ & $\begin{array}{c}0.033 \\
(0.05)\end{array}$ & $\begin{array}{c}0.116^{* *} \\
(0.056)\end{array}$ & $\begin{array}{c}0.116^{* *} \\
(0.056)\end{array}$ \\
\hline Non-white & $\begin{array}{c}0.117^{*} \\
(0.067)\end{array}$ & $\begin{array}{c}0.16^{* *} \\
(0.063)\end{array}$ & $\begin{array}{c}0.112 \\
(0.07)\end{array}$ & $\begin{array}{c}0.111 \\
(0.07)\end{array}$ \\
\hline CESD-score & $\begin{array}{l}0.003 \\
(0.003)\end{array}$ & $\begin{array}{c}0.009^{* * *} \\
(0.003)\end{array}$ & $\begin{array}{l}0.003 \\
(0.003)\end{array}$ & $\begin{array}{l}0.003 \\
(0.003)\end{array}$ \\
\hline Income & $\begin{array}{c}0.06^{* * *} \\
(0.012)\end{array}$ & $\begin{array}{c}0.092^{* * *} \\
(0.012)\end{array}$ & $\begin{array}{c}0.059^{* * *} \\
(0.013)\end{array}$ & $\begin{array}{c}0.062^{* * *} \\
(0.012)\end{array}$ \\
\hline Observations & 11770 & 11770 & 10065 & 11770 \\
\hline
\end{tabular}

${ }^{*},{ }^{* *}$ AND $^{* * *}$ INDICATE SIGNIFICANCE AT LEVELS 90, 95 AND 99, RESPECTIVELY.

RESUltS ARE COEFFICIENTS. 
Figure A.1: Reported versus Constructed Partnership Length

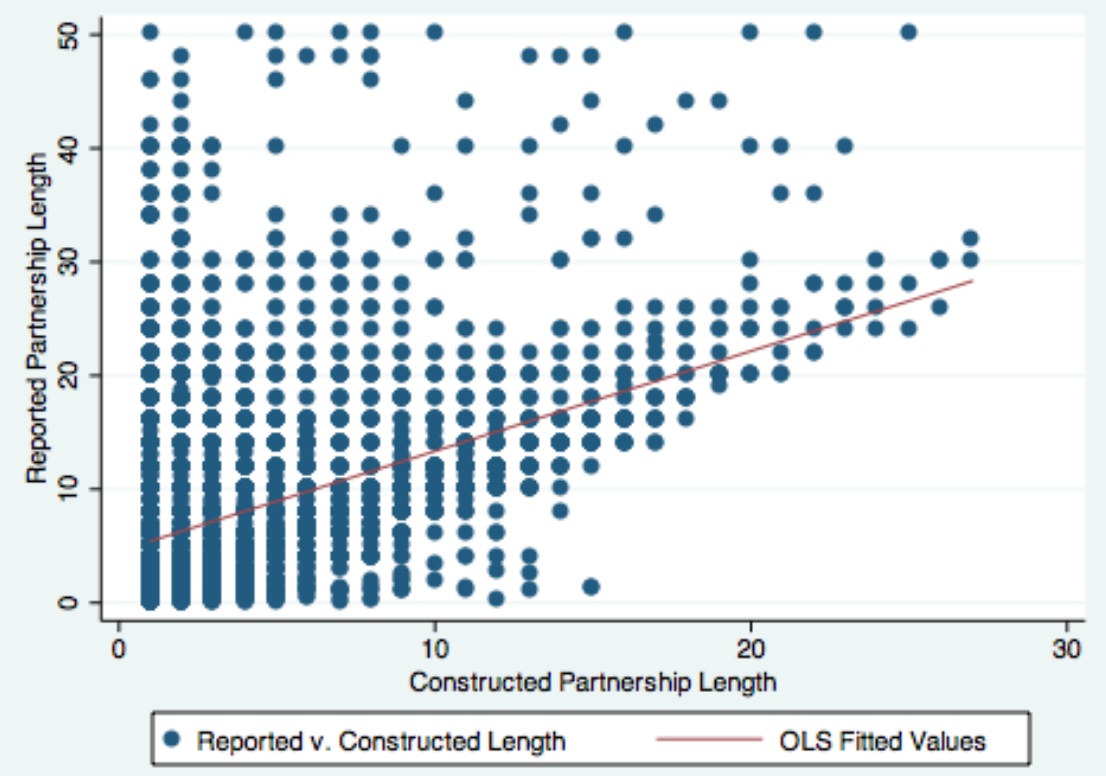

